\title{
Publicidade e lingua galega na prensa escrita. Estudo dun corpus composto por materiais de cinco xornais galegos
}

\author{
Carme Silva Domínguez. \\ Universidade de Santiago de Compostela
}

\begin{abstract}
Resumo:
Neste traballo presentamos unha cata na situación do galego nos xornais do país a través do exame da lingua dos textos publicitarios que neles se insiren. A nosa tese consiste en que a diversa posición que cada cabeceira ocupa no sistema mediático galego e estatal repercute en gran medida nas súas decisións lingüísticas. Tamén no caso da publicidade, a pesar do seu carácter supostamente "libre" e aberto á sociedade, é posible albiscar pegadas e influencias das especiais circunstancias que determinan o posicionamento político, social e por suposto lingüístico dos diarios.
\end{abstract}

Palabras chave:

publicidade, lingua dos xornais, sistema mediático galego.

\begin{abstract}
:
TIn this work we present an insight into the situation of the Galician language in the country's newspapers by means of an examination of the language in the publicity texts that appear in them. Our thesis is that the different position each heading occupies inside the Galician as well as the national media system has great repercussions on its linguistic choice. Also in the case of publicity, in spite of its nature supposedly "free" and open to society, it's possible to see effects and influences from the special circumstances that determine the political, the social and of course the linguistic position of the different headings.
\end{abstract}

Key words:

publicity, newspaper language, Galician media system.

\section{Introdución ${ }^{1}$}

A situación da lingua galega nos medios de comunicación escritos é obxecto de permanente debate e controversia, e sempre por razóns de moi diverso tipo. A discusión céntrase primeiramente en aspectos de natureza cuantitativa, pois a ecua-

1 Este traballo presentouse primeiramente como segundo exercicio da miña oposición ao corpo de Profesores Titulares de Universidade, que tivo lugar en Santiago en decembro de 2003. Se menciono este feito é coa finalidade de deixar constancia do meu agradecemento ás proveitosas observacións e críticas que á exposición lle fixeron os doutores Ramón Lorenzo Vázquez, Camiño Noia Campos, Burghardt Baltrusch, Josefa Postigo Aldeamil e Francisco Xavier Varela Barreiro. Os erros, evidentemente, son todos da miña responsabilidade. 
ción que permitiría igualar o sen dúbida importante investimento das administracións na galeguización dos medios cunha sólida presenza do galego nos xornais do país non pode ser máis inexacta no noso caso. Aínda que en menor medida e como aspecto que se sitúa nun segundo plano no referente aos medios escritos, tamén se discute arredor do modelo de galego mellor para os xornais: a queixa en torno á contaminatio lingüística inherente a textos que se xeran contra reloxo e sen excesivo coidado prodúcese tanto da parte do galego (pois a influencia estrutural e léxica do castelán non deixa de producirse cando o que se fai é traducir teletipos a correr) como desde a perspectiva do castelán (en que o linde exacto entre o mantemento da natureza galega de certas institucións e a utilización do español para determinadas informacións nunca acaba de atopar un asentamento non contestado).

A análise que se achega neste traballo ten como finalidade máis evidente a de fornecer unha serie de datos que, desde o seu carácter concreto e puntual -pois están tomados dunha única semana do mes de setembro de 2003- son susceptibles de presentaren unha lectura máis xenérica, e permitirnos así deducir algunha invariante tanto do estado da lingua galega no mundo publicitario e na prensa escrita, como do posicionamento e perspectiva desde a que as distintas cabeceiras interpretan a situación lingüística de Galicia. No noso traballo optamos tamén por elaborar un prólogo algo extenso en que pretendemos achegar un exame pausado dos condicionantes que determinan as circunstancias de actuación -e non só lingüísticas- dos xornais galegos, inmersos no momento actual nun abano de desafíos que, de non se afrontaren con intelixencia e habilidade estratéxica, poden levar a moitas das cabeceiras da comunidade á decadencia e mesmo á desaparición. A análise con certa extensión da realidade prensa en Galicia é cuestión previa ao tratamento puntual non só de aspectos relacionados coa lingua da publicidade, como é o caso desta nosa achega, senón que se erixe tamén en marco axeitado e necesario para o coñecemento de calquera outro tema relativo á estrutura dos propios xornais, e desde logo é fundamental no estudo global da lingua nas cabeceiras galegas.

Dentro dos medios escritos, imos utilizar unha clasificación cómoda e esquemática que nos permita individualizar o xornal, definido basicamente pola súa periodicidade diaria e polo modelo de presentación formal e organización temática a que se acolle (con semellanzas no tipo de papel, tamaño de folla, distribución de contidos, etc.) fronte a un amplo abano de publicacións diversas: revistas, semanarios, etc., con temática, intencionalidade e ámbito de difusión tamén heteroxéneos entre si. Son variadas as causas que aduciremos deseguido para xustificar o feito de nos centrarmos no primeiro tipo de produto e non intentar a análise das cabeceiras "paraxornalísticas" que teñen Galicia como ámbito de difusión fundamental, algunhas monolingües en galego (Tempos Novos, A Trabe de Ouro, 
A Nosa Terra ${ }^{2}$ etc.) e moitas outras, sobre todo as publicacións que se dirixen a colectivos específicos de cidadáns ou a áreas xeográficas concretas, bilingües ou monolingües en castelán.

En primeiro lugar, cómpre ter en conta as cifras de penetración social da prensa sensu stricto, que non son comparables, pola súa magnitude, ás de ningunha outra publicación periódica de ámbito galego. En segundo termo, o elevado nivel de estandarización estrutural dos xornais a que antes aludimos é de grande utilidade nun estudo como o que nos propoñemos levar adiante, pois permitiranos destacar os aspectos comúns a varias cabeceiras, aínda existindo, así mesmo, diferenzas na presentación dos contidos (pero a maior parte das seccións, ordénense como se ordenen -e esta cuestión tampouco non é gratuíta ou irrelevante, mesmo desde o punto de vista lingüístico- ten o seu parangón en todas as cabeceiras). Como terceira razón argüímos que o ámbito de actuación espacial de cada un dos xornais, que conxuntamente conforman unha especie de "mapa de Galicia", é tamén importante para a análise de cuestións de carácter lingüístico, pois sabido é que a situación da lingua non é a mesma nas distintas áreas xeográficas do país. Por último, un dos argumentos máis poderosos para xustificar esta nosa decisión foi a existencia dunha moi ampla bibliografía que analiza a situación e perspectivas das cabeceiras xornalísticas galegas desde múltiples puntos de vista, e achega un gran número de datos sobre da súa difusión, das características da empresa editorial que as edita, etc. A lectura e reflexión deste material bibliográfico de partida permitiunos a elaboración por extenso do marco de análise previo que conforma o apartado terceiro do artigo.

\section{Estrutura do traballo e deseño do corpus}

Segundo acabamos de afirmar, na achega daremos moita importancia a todas as cuestións previas relativas á configuración do sistema xornalístico galego, pretendendo con este modus operandi a elaboración dun marco de aproximación válido non só para o traballo de campo que se deseña, senón para o desenvolvemento de calquera outro subtema que puider interesar en relación cos aspectos lingüísticos dos medios de comunicación escritos en Galicia. Tal circunstancia explica a demorada análise que de seguido se presenta, quer do marco global de actuación da prensa no Estado e en Galicia, quer dos datos que falan da relación entre a lingua e o fenómeno publicitario, e tamén do coñecido material en que se presenta e avalía a situación do galego na prensa escrita en xeral.

Con respecto ao traballo sobre un corpus, que complementa e serve de campo de proba da validez dos datos inferibles a partir das cuestións previas ás que vimos de

\footnotetext{
2 Este semanario ocupa desde a nosa perspectiva unha posición intermedia entre o xornal, ao que se asemella na presentación externa e na distribución temática de contidos, e os outros tipos de publicacións, con algunha das cales concorda na periodicidade (en calquera caso non é un diario).
} 
aludir, este consiste na análise dos aspectos lingüísticos de índole cuantitativa relacionados coa publicidade extraídos de cinco xornais galegos nun período dunha semana, en concreto a que vai do 15 ao 21 de setembro de 2003. Escollemos este arco cronolóxico porque, ao traballarmos con prensa escrita, parece útil o emprego da semana como unidade de referencia, dada a diversificación e especialización de contidos que amosan as cabeceiras: así, os luns e sobre todo os martes a información deportiva acada unha maior entidade e mesmo se pode presentar como caderniño á parte; hai días especialmente dedicados en cada xornal ao mundo educativo, tanto universitario como non universitario; os xornais da fin de semana presentan diferenzas notorias a respecto dos dos días laborables, tanto no tipo de contidos que inclúen como no número de páxinas de que constan etc.

As cabeceiras que serán obxecto da nosa análise de campo son as seguintes: La Voz de Galicia (LVG), Faro de Vigo (FV), El Correo Gallego (ECG), El Progreso (EP) e Galicia Hoxe (GH). Non nos pareceu operativo, a pesar de que daría lugar a unha achega máis exhaustiva, o exame da totalidade dos títulos xornalísticos galegos, e desbotamos aqueles que teñen unha vixencia moi local e en xeral unha tirada reducida, condicionada polo limitado do seu ámbito de difusión ou polo recente da súa creación -El Ideal Gallego, Diario de Pontevedra, Diario de Ferrol, La Opinión de A Coruña, Diario de Bergantiños etc.-. Escollemos tres cabeceiras con vocación de implantación en toda a comunidade: LVG, ECG e GH, esta última ineludible na análise de calquera aspecto relacionado coa lingua na prensa. FV adscríbese ao modelo de xornal de carácter local-provincial, categoría esta que conta con varios representantes en Galicia, pero ao noso xuízo o xornal vigués non pode ser obviado nun traballo destas características por causa da súa tirada: é a segunda cabeceira de Galicia tanto en número de exemplares vendidos como no relativo aos seus datos de difusión.

Por outra parte, a importancia de ECG para calquera traballo que se refira á relación entre lingua e prensa é evidente, por ser esta a cabeceira matriz do Grupo Correo Gallego, que decidiu na década dos 90 a creación dun xornal monolingüe en galego: a priori, poderiamos supoñer unha boa disposición de cara ao emprego da nosa lingua nun diario pertencente a unha empresa que toma unha decisión estratéxica de tal magnitude. Un aspecto máis de interese en ECG é o feito de que, segundo os datos referidos á transición entre os séculos XX e XXI que presenta López García (2002: 45), foi ECG o diario que máis medrou en termos de difusión neste momento cronolóxico, pois nun só ano, entre 2000 e 2001, conseguiu máis de catro mil novos lectores ${ }^{3}$.

3 Con todo, cómpre tamén sinalar que de acordo cos datos máis recentes dos dispoñibles, ECG sofre nos últimos tempos un certo estancamento na súa difusión. No momento de elaborar o artigo que presentamos, a cabeceira aparecía no Estudio General de Medios de febreiro a novembro de 2003 -a que despois nos referiremos- no posto 44 do total da prensa española. A última edición deste instrumento de medición, referida ao período comprendido entre outubro de 2003 e maio de 2004, non recolle o xornal compostelán entre os cincuenta máis difundidos do Estado. 
Finalmente, someteremos tamén a exame os datos relativos a EP, un bo representante da prensa local que ten a súa raíz nunha empresa de carácter familiar pero que procura tamén diversificar o negocio e abrirse a novas perspectivas de comunicación neste arranque de milenio.

O traballo de campo achegará en primeiro lugar algúns datos que nos permitan caracterizar a relación que cada xornal mantén co mundo da publicidade, desbotados os anuncios por palabras 4 : a cantidade global de textos publicitarios que insire, o tamaño e organización por seccións destes, a importancia da publicidade institucional no conxunto das mensaxes, a autopublicidade, etc. Examinaremos logo os aspectos de relevo para a caracterización da relación entre lingua e publicidade nas distintas cabeceiras, tamén desde un punto de vista cuantitativo: veremos o peso que os anuncios en galego teñen na propia publicidade do xornal, nas mensaxes das institucións, nas de empresas privadas etc. Todos estes aspectos servirannos para ter unha visión bastante apurada das circunstancias en que se desenvolve a presenza da lingua galega nos textos publicitarios que se insiren nos principais xornais do país, e cremos que tamén pode ser útil para deducir aspectos do posicionamento real das diferentes cabeceiras perante a situación lingüística galega.

\section{Aspectos previos que cómpre ter en conta}

\subsection{A estrutura dos grupos xornalísticos do Estado español}

Para esta parte do traballo baseeime sobre todo en Reig (1998), e nas diversas achegas que Francisco Campos Freire, só ou coa colaboración de Xosé López García, ten publicado nos últimos anos, en especial Campos [Freire] (2002) e tamén Campos Freire / López García (2000). Ofrecerei así mesmo datos que baixei de Internet, procedentes da enquisa coñecida no ámbito español como Estudio General de Medios (EGM) ${ }^{5}$, e que parece ser interpretada -aínda que non sen certa polémica- como o indicador máis fiable da difusión dos xornais, moi frecuente-

4 Este tipo de mensaxes está a medio camiño entre a información de servizos que achega o xornal e a publicidade propiamente dita, e mesmo nalgunhas cabeceiras, nomeadamente nas dúas que son propiedade do Grupo Correo Gallego, faise difícil realizar o deslinde en firme entre publicidade e anuncios por palabras. Con todo, cremos que é factible manter que existe unha diferenza entre ambas as categorías de materiais (emisor individual fronte a emisor empresarial; diversidade de finalidades fronte a incremento de vendas como finalidade única etc.), e por esta razón excluímos da análise os anuncios por palabras.

5 Sempre que se aluda no presente traballo aos datos do EGM e se non se indique expresamente o contrario, débese entender que me refiro á versión correspondente ao intervalo comprendido entre outubro de 2002 e maio de 2003. No momento de corrixir o traballo para a súa publicación (novembro de 2004), xa hai outras dúas enquisas posteriores dispoñibles na rede, a máis recente das cales estuda a difusión dos xornais do Estado entre outubro de 2003 e maio de 2004. 
mente non concordante en absoluto coas súas cifras de venda pola influencia dos hábitos de lectura en espazos comúns.

Non é labor sinxelo o de sintentizar con acerto os trazos fundamentais definitorios do panorama mediático español no relativo á prensa escrita. Desde un punto de vista cronolóxico, os estudosos distinguen entre cabeceiras que viviron en tres séculos e aqueloutras que se implantaron exitosamente tras a caída da ditadura, momento en que se produciu a segunda gran revolución das empresas xornalísticas no século $\mathrm{XX}^{6}$. Tamén é moi pertinente a cuestión da titularidade, pois en xeral as empresas máis vedrañas xurdiron por causa da iniciativa empresarial dunha familia, e moitas delas manteñen en boa medida este carácter de institución familiar. Por contra, noutros casos o control económico dos diarios está en mans de corporacións de base tecnolóxica ou vencéllase ao capital dos grandes bancos. Cabería esperar que aos diferentes modelos de titularidade empresarial correspondese, así mesmo, un nivel de independencia ou vinculación cos poderes político e económico diferenciado en cada caso.

Con respecto ao tamaño, teriamos que referirnos non tanto aos xornais como empresas autónomas, autosuficientes e individualizadas, senón máis ben a grupos de comunicación, compostos na totalidade dos casos por varias cabeceiras e con investimentos que se ramifican tamén cara ao audiovisual (produtoras de TV, TV locais), cara á propiedade de axencias de prensa e mesmo cara á creación de empresas de investigacións sociolóxicas. Os datos de Reig (1998) para esta cuestión son xa antigos, pois non contemplan a absorción do Grupo Prensa Española, editor do xornal $A B C$, por parte do Grupo Correo. Máis actuais son os que achega Campos [Freire] (2002), quen falando do negocio mediático en xeral, incluída a prensa escrita, distingue un primeiro chanzo formado por tres xigantes na comunicación en España, cada un dos cales supera o $15 \%$ da difusión total dos medios: así, o grupo Correo-Prensa Española queda cun $18,6 \%$ da torta, Unedisa-Recoletos ${ }^{7}$ tamén cun 18,6\%, e Prisa, cun $15,8 \%$ da difusión. En total, pois, tres grandes grupos moi diversificados internamente repártense máis do 50\% do negocio da comunicación en España.

6 A primeira consistiu no peche das cabeceiras non afíns ao réxime franquista ao final da Guerra Civil, e na confiscación das demais, que pasarán a integrarse nunha rede de prensa paraestatal desmantelada contra finais dos anos 70, a prensa del Movimiento.

7 Lembremos que se trata do grupo editor do diario deportivo Marca, que no EGM de febreiro a novembro de 2003 acadaba unha difusión próxima aos dous millóns e medio de lectores, e que é de capital é fundamentalmente inglés e italiano; os datos máis recentes tomados do EGM indican que a cabeceira sobrepasa xa folgadamente o devandito limiar de difusión. Pola súa banda, Unedisa edita El Mundo, o segundo dos grandes xornais xeneralistas, pois sitúase moi por riba do millón de lectores.

8 Como é ben sabido, as "xoias da coroa" do grupo son o diario El País, o mellor posicionado no Estado segundo o EGM, con preto dos dous millóns de lectores, e a SER, cadea radiofónica líder, cunha difusión que duplica a súa máis inmediata seguidora, Onda Cero (case cinco millóns de oíntes fronte a pouco máis de dous, segundo os datos do último EGM). 
As cifras que vimos de expoñer permiten afirmar que a tendencia máis recoñecible das mencionadas como básicas polos distintos autores para a explicación do panorama mediático no Estado é a concentración, isto é, un único titular fai por acaparar a maior cantidade de medios que lle sexa posible. Máis en concreto e no que se refire especificamente ao ámbito xornalístico, cada vez é máis frecuente que as empresas que posúen as grandes cabeceiras se fagan con xornais pequenos, de ámbito local ou provincial, totalmente ou de maneira parcial: así rendibilízanse os custos de produción e en moitos casos asegúrase ou mellórase a rede de distribución do xornal matriz. A prensa local parece ser un bo negocio, e mesmo existe un grupo, denominado Prensa Ibérica, ben posicionado en canto á súa magnitude segundo os datos de Reig (1998), a que pertence un número crecente de cabeceiras locais (en Galicia desenvolve un papel moi destacado, pois adquiriu en 1986 Faro de Vigo e creou co arranque do milenio La Opinión de A Coruña).

Para abaratar custos, especialmente na distribución e na comercialización publicitaria, os grupos editores dos grandes xornais estatais acoden así mesmo a convenios de colaboración coa prensa rexional e local: interesante e novidosa é a fórmula ideada por El Mundo, de distribución conxunta, sen incremento de custo para o consumidor, con cabeceiras de menor ámbito de difusión -en Galicia, como é sabido, con ECG-. A xestión publicitaria tamén se fai a través dos grandes grupos: Campos [Freire] (2002) apunta que o Grupo Correo-Prensa Española controla a través da súa empresa de exclusivas publicitarias a comercialización dun gran número de xornais do Estado, entre eles LVG; pola súa parte, Gestión de Medios de Prensa, propiedade do grupo Prisa, estaba en 2002 en contacto con La Región con vistas a concretar "participacións societarias, xestión de materias primas e alianzas para a actividade da TV local ou para a xestión conxunta de publicidade a través da súa organización [...] de exclusivas de comercialización" (Campos [Freire] 2002: 16-17). Tamén os grandes grupos determinan o goloso negocio da elaboración e distribución dos suplementos dominicais: só os tres xornais maiores de difusión estatal achegan neste sentido unha oferta diferenciada. Taller de Editores, empresa á altura de 1998 controlada maioritariamente polo daquela Grupo Correo, elabora un suplemento que adquiren e distribúen boa parte dos xornais locais e rexionais, entre eles LVG. Con respecto a esta cuestión, algúns dos apuntamentos achegados por Reig son de grande interese: Santiago Rey, responsable daquela da devandita cabeceira galega, liderou en 1987 a iniciativa conducente a poñer en marcha a sociedade editora do suplemento, pero posteriormente tendeu a vender a súa participación na empresa, ata case un 21\% que lle cede ao grupo Correo en 1996.

Os datos relativos á expansión exterior dos grupos de capital español son máis ben modestos, ao noso xuízo: Reig (1998) sinala movementos con vistas a intervir no mercado iberoamericano (o antigo editor de El Ideal Gallego, Florencio Aldrey, foi pioneiro nesta experiencia americana, pois posuíu a un tempo a cabeceira galega e 
outras en Arxentina) e en diversos ámbitos europeos (Prensa Ibérica, a editora de $\mathrm{FV}$, ten unha gran penetración en Portugal, pois edita $A$ Capital en Lisboa e $O$ Comercio no Porto). Máis evidente é a tendencia á expansión peninsular de empresas doutros países europeos: véxase o moi significativo caso de Recoletos-Unedisa, por exemplo.

Concentración, expansión dos grandes grupos cara ao deseño de diversas formas de control dos grupos e cabeceiras menores, diversificación mediática e axilidade nos movementos expansivos parecen ser os trazos definitorios máis característicos do contexto en que se desenvolve a prensa escrita no Estado español. E todo isto cun número moi elevado de cabeceiras -pasan xa das 125 , incluída a prensa deportiva-, que tende mesmo a incrementarse nas últimas décadas. Dous datos poderían ser interpretados como en aparencia contraditorios a respecto de todo o anterior: o índice de lectura no Estado español situábase na fin do milenio escasamente por riba dos 100 exemplares por cada 1000 habitantes (o limiar inferior establecido pola UNESCO para considerar unha comunidade culturalmente desenvolvida) e aparecía claramente descompensado por comunidades ${ }^{9}$; por outra banda, o EGM máis recente fala dun índice de penetración da prensa escrita de só un 39,7\% -isto é, do total da poboación española, só algo menos do $40 \%$ le o xornal-, fronte ao $53,1 \%$ que conseguen as revistas, o $57,9 \%$ da radio e o rotundo $90,7 \%$ da televisión.

\subsection{Principais características do modelo galego de prensa}

Comezaremos esta breve aproximación aos trazos máis definitorios do mundo xornalístico galego cunha reflexión que tomamos prestada de Vilela Conde (2001): este profesional da prensa escrita afirma que constantemente se fala de crise no xornalismo, moi en especial en Galicia, por causa tanto da competencia dos medios audiovisuais como do importante posicionamento e progresivo acance no país do chamado "xornalismo de penetración", isto é, das cabeceiras editadas na capital do Estado. Con todo, os datos obxectivos, as cifras numéricas, indican o saneamento do sector (todos os diarios, a distinto nivel segundo a súa dimensión, son rendibles

9 Díaz Nosty (1999) inclúe unha clasificación das Comunidades Autónomas segundo o seu índice de lectura de xornais. O cimo ocúpano Euskadi e Navarra, con 188,5 e 174,7 exemplares por cada 1000 habitantes. No último posto sitúase Castela-A Mancha, con unicamente 52,3. Galicia ocupa unha posición intermedia na táboa (a undécima), e é a última comunidade daquelas que superan o índice 100 da Unesco: 103,9 xornais por cada 1000 habitantes, para este ano. Tendo en conta o feito de que os datos do EGM con que contamos, dos anos 2000-2003, refliten un incremento constante aínda que modesto do número total de lectores de diarios (de 12.597.000 nos albores do milenio pásase a arredor dun millón máis e medio máis, 14.000.005, ata novembro de 2003), previsiblemente debeu aumentar tamén a posición de España con respecto ao índice da UNESCO. En concreto é esperable que Galicia ascendese na escala, pois a difusión dos principais xornais galegos en número de lectores, LVG e FV, aumentou tamén segundo os datos do EGM. 
nos datos que se achegan na aproximación de que falamos) e mesmo de constante crecemento por causa da eclosión no mercado de novos xornais, en aparencia de reducidas dimensións (o último, que nós saibamos, Diario de Bergantiños). E todo isto partindo dun índice de lectura intermedio, máis ben baixo, no conxunto do Estado español.

O panorama xornalístico en Galicia pode ser resumido grosso modo nunha serie de trazos entre os que destacan os seguintes: o país conta cun elevado número de cabeceiras propias, boa parte delas de tradición secular e vencelladas á iniciativa dunha familia que leva á súa fronte varias xeracións; nas últimas décadas, e seguindo movementos xa apuntados no apartado anterior e vixentes por tanto no resto do Estado, as principais empresas xornalísticas galegas tenderon á diversificación a través da estratexia de penetración no mundo audiovisual, e convertéronse en conglomerados multimedia. Sirva de exemplo o Grupo Voz, que ademais de adquirir, con maior ou menor éxito empresarial, cabeceiras de fóra de Galicia, consta tamén dunha produtora de televisión, inclúe televisións locais e mesmo unha cadea de radio no nivel estatal, Radio Voz.

Orixinariamente, a unidade básica que definía a área de distribución de cada un dos xornais galegos era a provincia. Aínda ata datas moi recentes, a penetración interprovincial das cabeceiras pode ser valorada como moi reducida: segundo os datos de López García (2000) ${ }^{10}$, entre os anos 1976 e 1996 o intercambio de prensa entre provincias non só non medrou, senón que mesmo recuou en termos moi avultados porcentualmente. E isto, a pesar de que como é sabido desde os anos 70 tres cabeceiras galegas ensaian a estratexia da edicionalización para conseguir abrirse camiño en territorios diferentes do seu orixinario: El Ideal Gallego e ECG intentárono, ademais de LVG, pero con poucos resultados; só este último xornal mantivo e consolidou o sistema, cun importante éxito en termos de difusión, o que non impide que, segundo os datos máis recentes dos que dispoñemos, aínda tres cuartas partes do volume total de xornais vendidos da cabeceira o sigan sendo na provincia da Coruña. Visto desde a perspectiva do momento actual, podemos afirmar que das estratexias de ampliación consistentes na edicionalización só queda en pé o proxecto de LVG. No resto dos casos, parece que se constata a falta de viabilidade de proxectos de ámbito autonómico, isto é, as dificultades para a consolidación dun xornal rexional, en terminoloxía de López García (2000), ou de vocación e estratexia rexionalista, tomando a etiqueta de Álvarez Pousa (1999).

Unha segunda vía deseñada para a apertura a novos mercados de cabeceiras de vigor local e provincial consistiu na creación de xornais "adscritos" a un principal e localizados noutros espazos: ocorreu co desaparecido Faro de Orense, depen-

${ }^{10}$ Páxinas: 79 (gráficos 12 e 13), 83 (gráficos 14 e 15), 89 (gráficos 16 e 17) e 93 (gráficos 18 e 19). 
dente de FV; ocorre con Atlántico Diario con respecto a La Región, pero as cifras de lectores/día do xornal vigués son moi inferiores ás que consegue FV no mesmo territorio; tamén con La Opinión de A Coruña, integrado no mesmo grupo que FV; con Diario de Pontevedra, na actualidade integrado no Grupo El Progreso, e máis recentemente é un recurso en que se apoia a expansión de El Ideal Gallego fóra da cidade herculina.

Unha característica máis do contexto xornalístico galego é a existencia dun xornal fortemente preeminente en termos de difusión. O liderato de LVG dentro da prensa galega é evidente sexa cal sexa o dato numérico que se examine: en primeiro lugar, o EGM dá conta da moi boa posición relativa desta cabeceira no ámbito da prensa española, pois ocupa o quinto posto, cunha difusión estimada de 680.000 lectores/día, e sitúase xusto por debaixo da prensa de difusión estatal, incluídas as cabeceiras deportivas ${ }^{11}$; en segundo termo, o exame da evolución da difusión da cabeceira entre 1976 e 1996 (López García 2000: 97) revela que o xornal conseguiu unha cuarta parte da súa difusión neste intervalo de vinte anos, e que foi no inicio da década dos noventa do pasado século cando a cabeceira deu superado o límite dos cen mil lectores/día ${ }^{12}$.

Unha panorámica que contemple os aspectos esenciais do sistema xornalístico galego coa finalidade de trazar calquera análise lingüística debe glosar tamén a importancia e características da difusión de O Correo Galego, na actualidade GH. A cabeceira naceu con vocación de se converter nun xornal que tomase Galicia como ámbito de actuación global. Así e todo, tanto a orientación ideolóxica e o tipo de relacións que desde o principio o diario estableceu co poder político, como a súa pobre e reducida estrutura -en termos xornalísticos: inclinábase claramente por cuestións culturais, podía ser interpretado como un suplemento de cultura diario algo ampliado- restáronlle sen dúbida credibilidade e interese precisamente entre aqueles sectores aos que a priori se dirixía, os grupos sociais comprometidos activamente coa defensa da lingua. Parécenos significativo o feito de que $O$ Correo Galego nunca fose controlado pola Oficina de Xustificación da Difusión. Descoñecemos, por ser aínda moi recente, a repercusión que puideron ter na tirada

11 Os datos do EGM de febreiro a novembro de 2003 indican que LVG mesmo aparecía naquel momento por riba do catalán La Vanguardia; na máis recente versión da enquisa que coñecemos, a cabeceira catalá volve superar LVG, aínda que esta segue a se achegar, paseniñamente, aos setecentos mil lectores. Sexa como for, é máis que meritorio para un xornal editado e lido practicamente en exclusiva en Galicia o feito de que poida atuar un dos grandes da prensa no nivel estatal.

12 Con todo, en López [García] (2002: 45) dáse conta dun certo estancamento do número de exemplares diarios vendidos de LVG no arranque do terceiro milenio: así, o balance do intervalo comprendido entre 1999 e 2001 é negativo en termos de vendas. Non sabemos se os datos máis recentes son tamén máis positivos, vista a espectacular evolución que a cabeceira tivo nos últimos anos en termos de difusión, segundo o EGM. 
da cabeceira as significativas transformacións que nela se operaron en 2003: mudanza na denominación, cambios estruturais, ampliación do número de páxinas etc. ${ }^{13}$.

Este panorama da situación da prensa en Galicia non queda completo sen achegar aínda algúns datos máis: por exemplo, o constante incremento da difusión da chamada "prensa de penetración", isto é, a prensa editada en Madrid e concibida edicionalmente ou non ${ }^{14}$. López García $(2000)^{15}$ proporciona datos acerca da entidade cuantitativa deste avance na difusión: no intervalo comprendido entre 1976 e 1996, dun $8 \%$ pásase a un $23 \%$ de penetración da prensa estatal na provincia da Coruña, dun $11 \%$ a un $25 \%$ en Lugo, en Ourense dun $15 \%$ a un $33 \%$, e finalmente en Pontevedra o aumento leva a proporción de lectura dos xornais estatais dun $14 \%$ na primeira destas datas a un $28 \%$ na última. Grosso modo, entre un cuarto e un terzo do total dos xornais vendidos en Galicia nos últimos anos do século pasado corresponde a cabeceiras de fóra do país. Así mesmo, os modos de penetración dos xornais de fóra diversifícanse, e entre as novidades cabe sinalar o orixinal acordo de distribución entre ECG e El Mundo. Á difusión directa das cabeceiras foráneas hai que engadir modos de control indirectos: o grupo editor de La Región está participado por capital foráneo, e mesmo o poderoso Grupo Voz, segundo indicamos anteriormente, ten acordos en aspectos tan cruciais como a publicidade cunha central de compra propiedade do Grupo El Correo-Prensa Española.

O exame da crecente incidencia da prensa de penetración en Galicia debe completarse aludindo aos datos que permiten albiscar a existencia de diferenzas importantes entre o lector-tipo dos produtos xornalísticos autóctonos e dos foráneos. Neste sentido, é de grande interese a información achegada por Álvarez Pousa (1999: 167171), en que se examinan as características das persoas que consomen prensa en

13 Na edición dixital de ECG, na véspera do Día das Letras de 2003 (data en que se consumou o cambio de denominación) afirmábase o seguinte: "GH nace [...] cunha decidida vontade de independencia e de autoafirmación, cun novo e máis atractivo deseño, máis páxinas, novos contidos, a incorporación de novos profesionais e unha maior e máis elaborada oferta informativa". Parece, pois, que tras case unha década de experiencia o Grupo Correo Gallego se decidiu a poñer no mercado un auténtico proxecto de diario, e non só unha "folla parroquial", como socarronamente se lle ten chamado, que xustificase a elevada contía da subvención con que a administración autonómica financiaba a lealdade, non sabemos se só lingüística, da empresa. Si é certo que a nova cabeceira ten máis páxinas, unha estrutura xornalística máis ortodoxa e un deseño máis elaborado; tamén o é, como non podía ser doutro xeito, que a orientación ideolóxica desde a que se relatan as noticias segue sendo a mesma. Con todo, e segundo indicamos anteriormente, non podemos valorar aínda os beneficios ou prexuízos que reporta ao xornal a modificación de estratexia.

14 En xeral as edicións galegas das cabeceiras estatais pouco máis achegan que unha maior rapidez na distribución ao se contar con plantas de impresión en Galicia e, canto a contidos, unha mínima axenda de servizos.

15 O desglose numérico do incremento que ofrecemos de seguido atópase nos gráficos a que aludimos na nota 10 do traballo. 
Galicia de acordo coas seguintes variables: clase social, hábitat, nivel de estudos, sexo e idade. Hai algúns aspectos que son claramente coincidentes coas tendencias xerais que se detectan no nivel estatal: len máis xornais os homes do que as mulleres, e máis as persoas de idade intermedia do que os máis novos ou os máis vellos.

Parece máis significativo sinalar aquelas tendencias diferenciais, e que neste caso falan da existencia dunha clara escisión nos lectores de prensa de Galicia, en función da clase social, do lugar de residencia e da formación. En efecto, algunhas cabeceiras, as vencelladas na súa difusión ás provincias do interior de Galicia, son preferidas polas persoas con menor formación e máis feble posición social (véxanse os datos referidos a EP e La Región nos cadros das páxinas 167, 168 e 169: case un $40 \%$ dos lectores destas cabeceiras non ten estudos primarios e pertence á clase social baixa ou media baixa). Os diarios ligados a áreas máis urbanizadas do país presentan niveis mellores de fidelidade entre as clases máis podentes. Pero aínda máis preocupante parece o feito de que os xornais de fóra de Galicia que se consomen no país son lidos por persoas ben situadas e influentes dentro da sociedade galega. A este respecto, afirma Álvarez Pousa (1999: 175):

Os datos fan pensar en que a unha boa parte dos lectores que posúen un capital cultural alto non os conseguiu fidelizar a prensa galega. É un lector desasosegado, cambiante en función da cobertura intelectual e propiamente informativa que lles acheguen os xornais. Faro de Vigo, El Progreso e La Región perden unha parte considerable desa audiencia nos últimos anos, coincidindo nos tres diarios cunha estratexia de popularización informativa tendente a asegurar o mercado provincial no que cada un deles é líder. [...] Aguanta mellor La Voz de Galicia, malia que tamén veña perdendo a ritmo máis lento o lector de clase alta ou media alta. É El Correo Gallego o xornal que proporcionalmente ofrece o número máis alto de lectores con ese perfil social.

\subsection{Publicidade galega, publicidade en galego}

É lugar común o sinalamento da importancia da publicidade dentro da sociedade moderna, importancia non só económica (como un dos principais procedementos para a consecución do éxito comercial dun produto) senón tamén simbólica e ideolóxica (cfr. por exemplo Cermeño 1993 para unha visión simple pero precisa e clara do papel deste fenómeno na sociedade de consumo en que vivimos). De xeito intuitivo, todos sabemos que a publicidade é unha ciencia aplicada, e coñecemos tamén a importancia que para a propia configuración da imaxe pública da lingua e, indirectamente, para a mellora dos índices reais que a definen, ten a presenza do galego neste ámbito.

Tamén cabe considerar ben coñecidas as circunstancias específicas relativas á relación entre lingua galega e publicidade nos medios audiovisuais. En síntese, parece 
que os cidadáns non ven de xeito moi positivo a utilización do castelán na publicidade en medios galegófonos por definición, e nomeadamente na TVG (cfr. a este respecto Fernández Rodríguez / Rodríguez Neira 1986: apéndice 2, pregunta 81; Ramallo / Rei-Doval 1995: 28 -gráfico 2-; 32 -gráfico 4-e 33 -gráficos 5 e 6-) . A propia TVG leva case unha década lanzando campañas tendentes a mellorar os niveis de utilización do galego na publicidade e os resultados que comezan a albiscarse poden ser valorados como un éxito significativo: desde unha porcentaxe para o 96 inferior a un cuarto da publicidade en galego na cadea pública, pasouse en 2001 a unha proporción 40-60 favorable á nosa lingua (Ramallo 2002: 147). Se os números nos parecen modestos ou discretos, deberiamos ter en conta os aspectos desfavorables que hai que solventar: a elaboración de campañas para o audiovisual é máis custosa e complexa do que para os medios escritos.

En ocasións, e de forma un tanto paradoxal, semella máis doado convencer as multinacionais para o emprego do galego do que captar o interese e motivación de empresas máis modestas, de capital ou localización galegos. Este fenómeno, que xa se sinalaba en Campos Freire (1995), debe ser analizado con tento. Non se trata simplemente, cremos, de que as grandes empresas "vaian por diante" na detección de necesidades ou demandas concretas da sociedade, senón máis ben de que estas procuran "modificar a imaxe de empresa foránea con intereses alleos a Galicia" (Ramallo 2002: 148). Prodúcese así o paradoxo de que as grandes multinacionais se "galeguizan" tamén lingüisticamente, como unha estratexia de arraizamento ficticio, en tanto que as empresas de capital galego prefiren publicitarse con aires "cosmopolitas", talvez pensando que así van convencer o futuro consumidor da súa proximidade a estándares de calidade globais (pensemos, por exemplo, no mercado do leite envasado).

Adiantando aspectos que de seguido agromarán de novo no estudo de campo, cabe destacar algúns trazos que caracterizan o mundo publicitario galego, isto é, o dos anuncios de empresas galegas producidos para un público galego (que lembremos que non son todas as mensaxes publicitarias que as persoas reciben de medios galegos). Cunha economía tendente ao minifundio empresarial, as diversas achegas que consultamos destacan tamén o reducido tamaño, escasa profesionalidade e curtas miras das axencias galegas -cfr. por exemplo Gutiérrez González (1996), Ramallo (2002: 145-146), Pena Rodríguez (2002) e Fandiño Alonso / Pena Rodríguez (2002)-. Estes déficits do sector sen dúbida afectan ao tipo de análise da situación lingüística galega en que os publicistas, implícita ou explicitamente, basean o seu traballo, e non favorecen a mellora da relación cuantitativa entre as dúas linguas na publicidade.

A carón das peculiaridades derivadas da febleza do mercado publicitario galego e da dependencia deste con respecto ao exterior, débese destacar tamén a que denominaremos "especialización temática" do galego en anuncios emitidos e deseñados 
desde os diferentes ámbitos do sector público, fronte á súa máis precaria instalación no ámbito das mensaxes empresariais propiamente ditas. Xa en Goyanes Vilar / Núñez Singala / Romero Rodríguez / Túñez López (1996), no que ata o momento actual xulgamos o máis completo traballo sobre o galego na prensa, agroma con respecto á publicidade a básica diferenciación entre publicidade institucional e publicidade non institucional. As cifras de emprego da lingua nunha e noutra son claramente diferentes, e estes autores mesmo chegan a afirmar que

a publicidade galeguizada [...] procede fundamentalmente das Xunta de Galicia, os concellos, as universidades e mais as deputacións provinciais. Só nalgúns casos aparecen colectivos ou entidades privadas -sindicatos, organizacións humanitarias, plataformas civís- que se anuncian en galego e, en menor medida, empresas, comercios e individuos (Goyanes Vilar / Núñez Singala / Romero Rodríguez / Túñez López 1996: 133).

No noso traballo de campo tentaremos comprobar se realmente segue en vigor a asociación entre publicidade en galego e publicidade institucional ou parainstitucional. De ser así, teriamos aquí a plasmación práctica da ideoloxía lingüística maioritaria en Galicia, pois parece ser lugar común, aceptado por boa parte dos cidadáns, a consideración de que son as administracións, e máis en concreto a Xunta, as institucións que deben detentar case en exclusiva o papel de promoción da lingua (cfr. neste sentido Fernández Rodríguez / Rodríguez Neira 1996: 452485). Tal modo de pensar equivale, ao noso xuízo, ao establecemento dun vínculo case que indeleble entre institucións e lingua, en tanto que a actividade privada se concibe como menos susceptible de ser intervida lingüisticamente.

\subsection{Prensa e lingua en Galicia}

Tamén este apartado previo o imos desenvolver de xeito conscientemente impresionista, pois partimos de que os datos básicos son dabondo coñecidos para todos. Hai varias achegas de relevo, ademais da pormenorizada información que presenta o traballo de Goyanes Villar / Núñez Singala / Romero Rodríguez / Túñez López (1996) a que vimos de aludir: Fernández Rei (1991) para a década dos 80, Goyanes (1993) para os primeiros anos da década dos 90, Alonso (1994) para o ano 1993, Ferro Ruibal (1998) para 1998 e elaborando ademais unha comparativa entre os diferentes momentos previos. Catas posteriores, que se limitan a constatar o mantemento da situación de base, atópanse nos Informes da comunicación en Galicia elaborados para o Consello da Cultura Galega nos anos 2000 e 2002. Como síntese, a pesar da diversidade metodolóxica dos traballos que dificulta a súa comparabilidade, pode ser boa referencia o gráfico 3 dos que se inclúen en Monteagudo / Bouzada (2002: 138), en que se observa con claridade o estancamento -ou cuasiretroceso- da evolución cuantitativa do galego na prensa, en porcentaxes que se 
sitúan sempre por debaixo do $5 \%$ do total de material lingüístico dos xornais.

A evidente fasquía negativa dos datos é aínda máis notoria se enmarcamos estes coidadosamente. En primeiro lugar, o investimento da administración na galeguización dos medios existe, ou cando menos podemos falar de poderosas subvencións aos distintos xornais que se xustifican con argumentos lingüísticos: para valorar a contía dos datos e a súa importancia relativa, non temos máis que examinar as cifras que se achegan en Monteagudo / Bouzada (2002: 137-140; 149, gráfico 4). En segundo termo, outro aspecto que contribúe a considerar en aparencia inexplicable a situación lingüística dos medios escritos en Galicia ten que ver coa existencia de datos, en forma de enquisas, que se orientan a demostrar a boa disposición da maioría dos cidadáns de cara a unha maior presenza do galego nos medios. Véxanse a este respecto os resultados da cata que se contén en Goyanes Villar / Núñez Singala / Romero Rodríguez / Túñez López (1996: 125) coa finalidade de "realizar unha aproximación descritiva e sincrónica ao comportamento e actitudes lingüísticas dos lectores de xornais galegos a través dun cuestionario". Desta primeira aproximación á enquisa sociolinguiística referida aos medios de comunicación, realizada no ano 1990 e en que as preguntas se referían tanto aos hábitos reais dos lectores (se lían ou non artigos de prensa en galego) como á posibilidade de que lesen ou aceptasen un xornal con maior presenza, ou escrito integramente, na nosa lingua, cabe destacar a orientación positiva das respostas: unha ampla maioría dos entrevistados afirma que non ten problemas de comprensión perante unha noticia en galego, e que as le efectivamente, e mesmo valora de maneira positiva a posibilidade dun incremento na utilización do galego na prensa, e negativamente a súa escasa representatividade actual. Enquisas realizadas con posterioridade van na mesma liña: así, por exemplo, en Vaamonde Liste (2002: 64), a máis recente achega da sociolingüística cuantitativa galega, centrada na cidade de Vigo, temos que un $53 \%$ dos entrevistados opina que deben usarse as dúas linguas na prensa en Galicia, un $41 \%$ que debe empregarse só o galego, e só un 5,4\% pensa que debe empregarse só o castelán. Nunha década, e se podemos extrapolar os datos de Vigo á totalidade de Galicia, a demanda de galego nos medios non só non diminuíu, senón que mesmo aumentou.

En consonancia con este sentir social, a máxima institución con responsabilidades en cuestións de lingua en Galicia, a Real Academia Galega, incluíu no documento de propostas enviado ao Goberno e mais ao Parlamento de Galicia a finais de 2001 a reiteración da demanda de achegarse a un $10 \%$ de prensa en galego ${ }^{16}$, o que en

${ }^{16}$ Cfr. Real Academia Galega (2001a e 2001b). Na elaboración deste artigo non tivemos oportunidade de consultar o Plan Xeral de Normalización da Lingua Galega recentemente aprobado polo Parlamento Galego, pero cabe afirmar que no momento actual este documento se erixe na constatación máis evidente e extensa da preocupación de diversos colectivos perante o estado de cousas que se examina neste traballo. 
realidade non supón máis que situarse en niveis que algúns medios xa conseguiran á altura de 1994. Hai demanda por parte das institucións encargadas de velar por cuestións lingüísticas, hai orzamento profusamente distribuído e hai boa disposición ao respecto por parte dos usuarios destes medios. Cabe preguntarse, pois, onde radica exactamente o problema.

Unha das posibles respostas, a que subscriben Goyanes Villar (1993), Goyanes Villar / Núñez Singala / Romero Rodríguez / Túñez López (1996) e Ferro Ruibal (1998), consiste en responsabilizar plenamente por unha banda os xornalistas, en tanto que elaboradores da noticia, e pola outra as empresas editoras dos xornais de Galicia, ás que se acusa dunha certa miopía non só social, senón mesmo empresarial. No segundo dos traballos mencionados, a tese apóiase nunha enquisa a que se someteu a xornalistas de varios medios escritos galegos no arranque da década dos noventa. A opinión destes profesionais é máis ben pesimista con respecto á presenza da lingua de Galicia nos medios: case dous terzos valora a utilización do galego na escrita como un atranco para a difusión dos contidos, aínda que unha porcentaxe similar afirma que estaría disposto a escribir integramente en galego. Ferro Ruibal (1998) non dubida en falar de factores como a comodidade e a escasa fluidez na lingua por parte dos redactores e a súa deficiente ou nula aprendizaxe do galego á hora de os xornalistas tenderen cara a un emprego preferente ou mesmo exclusivo do castelán.

Polo que respecta ás empresas xornalísticas, poderase afirmar que non existe vontade de incrementar a presenza da lingua, pero do que non hai dúbida, desde o meu punto de vista, é de que en cada unha delas se parte dunha determinada visión da situación linguiística do espazo para o que se concibe o produto que se deseña. Ás veces, especialmente naqueles medios de vigor local -El Ideal Gallego, FV- a estratexia parece consistir nunha especie de adaptación ao medio: dada a escasa e decrecente importancia que a lingua ten nos seus correspondentes núcleos urbanos, semella considerarse coherente o seu emprego en porcentaxes tamén notablemente reducidas no xornal local ligado a estes núcleos de poboación. O modus operandi de LVG é, ao noso xuízo, diferente: calquera xornal que aspire a consolidar unha dimensión galega, que queira definirse como xornal galego -e este parece ser o obxectivo da cabeceira- debe enfrontarse co capital simbólico e comunicacional da lingua, un dos principais elementos de cohesión e identidade diferencial do país. Con todo, a resposta en positivo a esta realidade non vén dada pricipalmente neste xornal por un maior incremento dos artigos en galego, senón que se tende a aplicar un mecanismo compensatorio consistente en empregar a lingua na difusión e no efectivo deseño dalgúns daqueles produtos promocionais ou semipromocionais que se distribúen conxuntamente co xornal, como veremos deseguida. 


\section{Estudo do corpus de traballo}

\subsection{Número de anuncios/día: porcentaxe en galego (gráficos 1 e 2)}

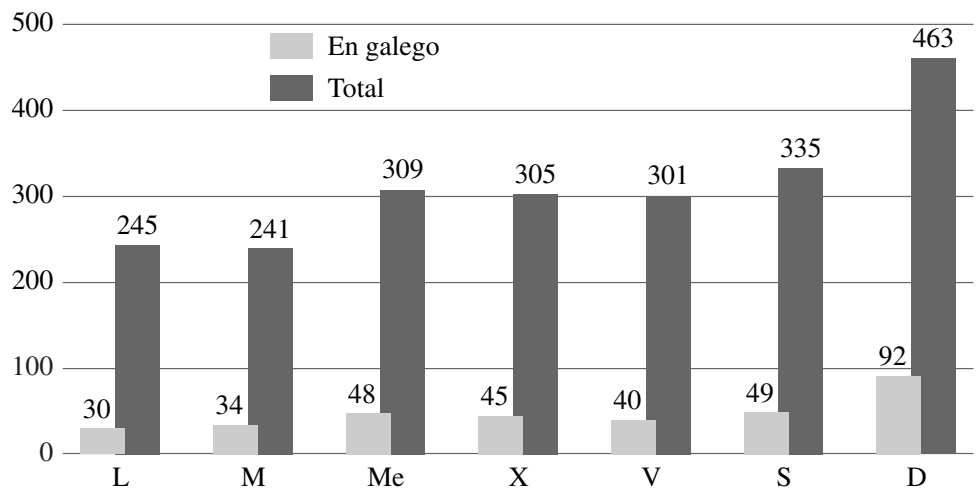

Gráfico 1. Número de anuncios/día.

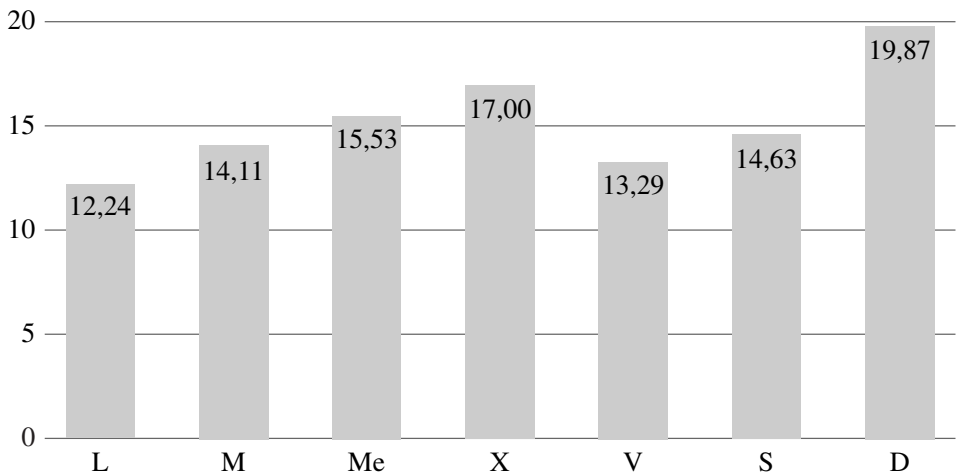

Gráfico 2. Porcentaxe de anuncios en galego.

A cantidade de mensaxes publicitarias que se insiren nas cabeceiras estudadas modifícase notablemente en función do día da semana en que nos situemos, desde o martes, que é o día en que aparecen menos promocións (241), ata o domingo, en que o número total do martes case se duplica (463). Por contra, as porcentaxes de anuncios en galego dese total mantéñense bastante estables entre os distintos días, variando só levemente ao se situaren algo por baixo, ou algo por riba, do $15 \%$ do total. Os domingos as cifras de galego na publicidade melloran sensiblemente, e achéganse ao $20 \%$, con toda probabilidade por causa do importante número de mensaxes institucionais que se inclúen neste día. 
4.2. Número de anuncios/xornal: porcentaxe en galego (gráficos 3 e 4)

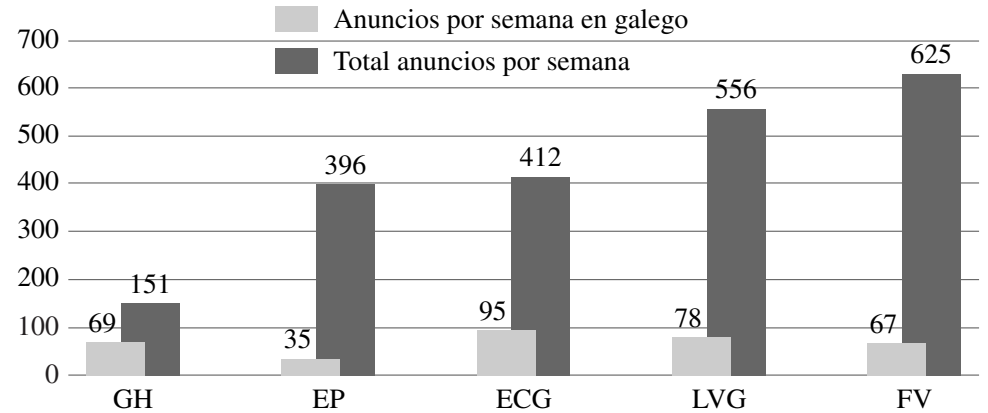

Gráfico 3. Número de anuncios por xornal

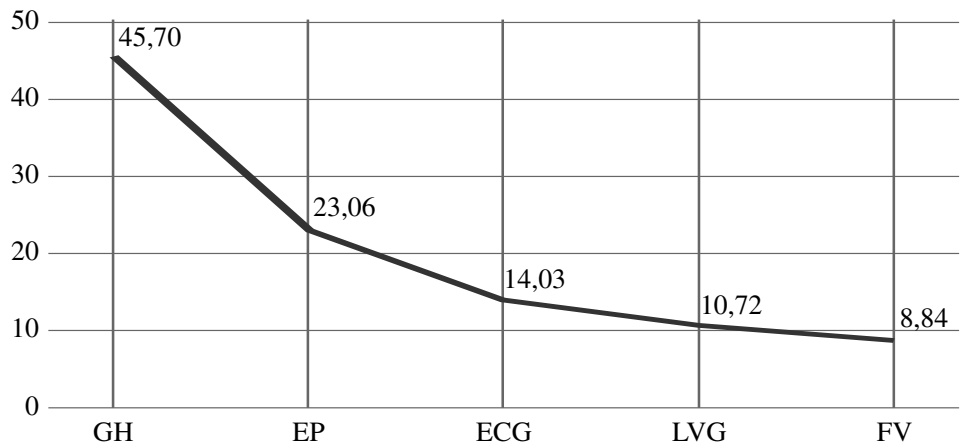

Gráfico 4. Porcentaxe de anuncios en galego.

Esta cuestión parécenos máis importante que a que se sinala no apartado anterior, pois permite caracterizar mellor as diferentes cabeceiras. No gráfico 3 obsérvase claramente que o peso do fenómeno publicitario, e podemos prever tamén que o peso do financiamento a el ligado é moi desigual nos diferentes diarios. O xornal que gaña a partida canto a número de anuncios que insire é LVG cun total de 625 , seguido a pouca distancia por ECG, con 556. Nunha posición algo máis moderada atópanse EP, con 412 anuncios no período estudado, e FV, con 396. Moi lonxe destas cifras queda $\mathrm{GH}$, con 151 anuncios en total.

O exame da porcentaxe destes anuncios por semana que son en galego presenta tamén variacións de interese (véxase gráfico 4). GH, que se promociona autocualificándose "o único xornal en galego", é unha cabeceira que non acada nin sequera o $50 \%$ da publicidade nesta lingua $(45,7 \%)$. Esta exigua porcentaxe contrasta coa información que a mediados da década dos 90 lles achegaba o seu actual director, Caetano Díaz Vidal, sobre OCG, a Gabriel Rei-Doval e Fernando Ramallo, que 
o entrevistaron para o seu libro Vender en galego, publicado polo Consello da Cultura Galega. Así, cando eles lle preguntaban “¿Cal é a política da súa empresa en relación coa publicidade?", Díaz Vidal explicaba que

A nosa política é moi clara. A publicidade pedímola en galego e sempre que podemos sae en galego. É dicir, que perdemos cartos; entendámonos, gastamos esforzo en traducir publicidade. Hai unha orde na dirección da casa que obriga a traducir ao galego a publicidade. Pero hai determinada publicidade que non podemos traducir. Por cuestións técnicas. Son anuncios nos que non dispoñemos desa trama ou desa familia de letra. E loxicamente hai que respecta-lo anuncio escrupulosamente.

Non imos deixar de publicar un anuncio porque teña que saír en castelán. A orde é publicar toda a publicidade, se podemos o $100 \%$, en galego; na que teña dificultades, tentar solventalas e traducir ata onde sexa posible, e no resto segui-los circuitos normais de calquera empresa. Porque en definitiva o que pretendemos é ser unha empresa normal. (Ramallo / Rei-Doval 1996: 228-229).

Se examinamos por exemplo os anuncios en portada, que nos parecen importantes posto que forman parte da páxina de maior visibilidade e difusión, temos que só están en galego nesta cabeceira os que aparecen o luns, o martes e o sábado, en tanto que o resto dos días da semana insírese publicidade en castelán tamén neste lugar de tan gran relevo.

Con todo, é evidente ao observar os datos do gráfico que a porcentaxe de anuncios en galego de GH é, con diferenza, a mellor das que temos, pois nesta cabeceira multiplícase por dous a cifra do segundo xornal da lista, EP, en que a publicidade en galego se sitúa no 23,06\% do total. En terceiro lugar aparece ECG, cun 14,03\%, e moi próximo LVG, cun 10,72\%. Finalmente, en FV as mensaxes publicitarias en galego non chegan ao $10 \%(8,84 \%)$.

\subsection{O galego en textos de autopublicidade das propias cabeceiras e de promocións (gráficos 5 e 6 )}

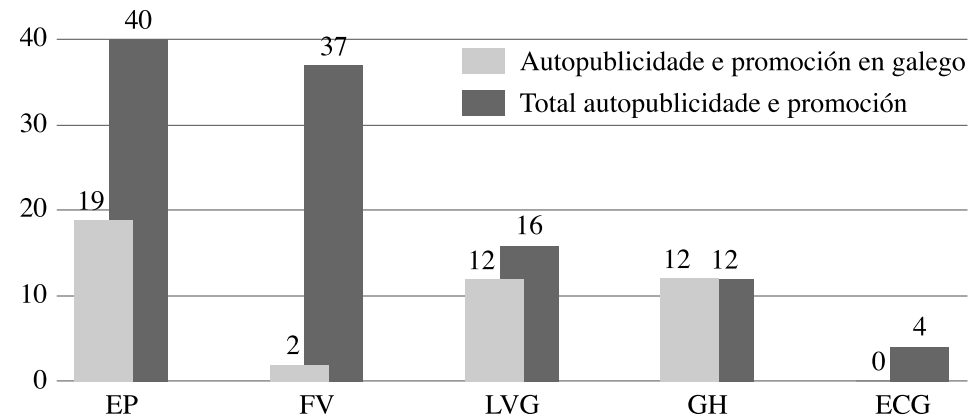

Gráfico 5. Autopublicidade/Promocións. 


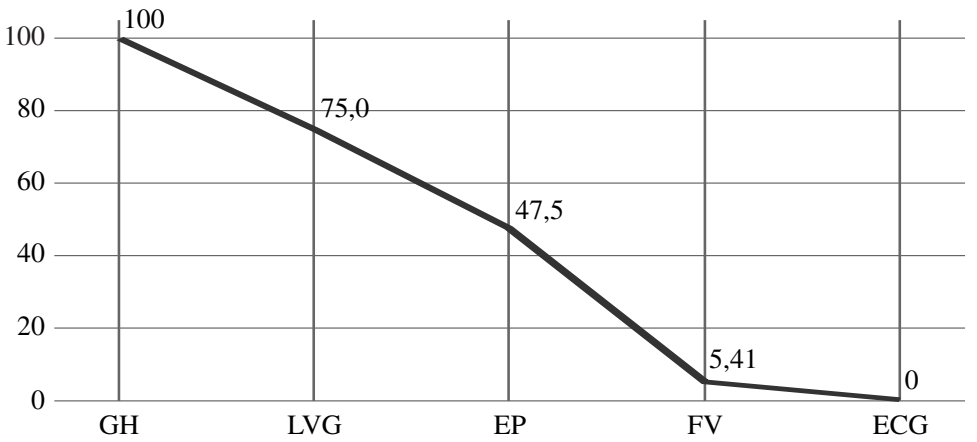

Gráfico 6. Galego en autopublicidade e promocións (en \%).

Como unha primeira vía para unha mellor caracterización cualitativa da relación entre publicidade e lingua, examinamos a praxe lingüística dos anuncios xerados e inseridos polo propio xornal, tanto aqueles que perseguen incentivar as vendas da cabeceira (e que utilizan só GH e FV) como aqueloutros con que se promociona calquera material elaborado ou distribuído pola empresa editora, sexa este de venda conxunta co exemplar ou non. No momento actual está certamente moi en voga a distribución do xornal á par de materiais promocionais de características moi diversas, desde aqueles relacionados co mundo da escrita (coleccións de novelas, enciclopedias, libros) ata obxectos de moi variada natureza e utilidade. Valentín Alejandro Martínez, profesor da Universidade da Coruña e ex-subdirector de $E l$ Ideal Gallego, dedica varios traballos, entre eles a súa tese de doutoramento, ao estudo deste tipo de mercadotecnia, e conclúe a escasa eficiencia do procedemento sobre todo á hora de fidelizar a audiencia: pode ser que se consiga un incentivo de vendas momentáneo, pero este é moi escasamente estable e duradoiro (cfr. por exemplo Martínez1999a, 1999b, 2002) . Con todo, no noso corpus só as cabeceiras pertencentes ao Grupo Correo Gallego renuncian a se implicaren nalgunha forma de agasallos-ofertas, e varios dos xornais que estudamos promocionan e distribúen un gran número de obxectos nos diversos días da semana.

No gráfico 5 aparece o número absoluto de anuncios deste tipo. Das cifras que presentamos despréndese que hai dúas cabeceiras, FV e EP, que destacan sobre das demais por causa da súa grande utilización dos recursos autopublicitarios. Con todo, obsérvanse diferenzas interesantes entre ambas, pois EP ofrece un número moi elevado, e de tipoloxía moi diferente, de materiais promocionais (A Gran Enciclopedia Gallega, a mochila de Shin-Chan, unha colección de novelas en castelán, a Enciclopedia Larousse, un CD compilatorio de música etc.), mentres que FV presenta unha cifra moi avultada a través sobre todo ${ }^{17}$ dun importante número

17 Tamén se promociona un xadrez que se distribúe co xornal, en calidade de agasallo. Xeralmente inclúese un único anuncio, de tamaño diverso e a cor, na portada de cada exemplar. 
de mensaxes de formato diverso en que se informa dun único produto, unha enciclopedia de cociña, a que dedica un número moi elevado de anuncios en cor, xeralmente dous ou tres en cada exemplar. LVG incentiva -e con maior mesura- basicamente a adquisición do Diccionario Enciclopédico Galego Universal ${ }^{18}$. ECG dedica anuncios, o luns, martes, mércores e xoves, á publicidade do libro Tierra de titanes, escrito por xornalistas vencellados á Editorial Compostela. A adquisición deste libro incentívase en castelán en ECG e en galego en GH, xornal que ademais inclúe todos os días dúas tiras de autopromoción xenérica da cabeceira nas follas antepenúltima e penúltima do exemplar, onde se sitúa a programación de televisión. Por outra parte, ambas as cabeceiras do Grupo Correo Gallego anuncian en castelán o Anuario de empresas de El Correo Gallego y Galicia Hoxe ${ }^{19}$.

Cremos que con independencia do éxito ou do valor comercial que supoña a utilización de estratexias autopromocionais e de agasallos, é moi importante o idioma que se escolle para facer este tipo de anuncios, pois nestes textos é o xornal o que establece un diálogo, nunha lingua ou noutra, co seu público. Neste sentido vemos cómo EP e LVG empregan ambas as linguas, non coa mesma proporción cuantitativa pois a escolla de idioma faise sempre en función do idioma que se presupón vencellado ao produto que se oferta: por exemplo, EP promociona en galego a mochila de Shin-Chan e a Gran Enciclopedia Galega, e en castelán a Enciclopedia Larousse e as colección de novelas; LVG tamén emprega o galego para incentivar as vendas do Diccionario Enciclopédico Galego Universal e o castelán para outros produtos non ligados explicitamente a Galicia. FV non tiña no momento en que fixemos a mostraxe ningunha oferta comparable a aquelas que se promocionan en galego nas cabeceiras anteriormente examinadas, e talvez por esta razón as súas cifras de emprego do galego na autopublicidade son moi baixas ${ }^{20}$ : só en dúas ocasións FV utiliza o galego para a autopromoción, e é para informar do seu suplemento "Faro da Cultura", que sae os xoves e, cando menos o día que eu o vin, vai todo en galego ${ }^{21}$; ECG promociona o libro Tierra de titanes en castelán, e GH en galego. No referente á publicidade do anuario da Editorial Compostela, a empresa opta por inserir a publicidade do produto unicamente en castelán, mesmo na súa cabeceira en galego.

Deste diálogo cabeceira-lector deducimos que EP e LVG desexan que se asocie a súa imaxe corporativa ao papel de promotores da cultura galega, en tanto que escollen o castelán para dar a coñecer aqueloutros produtos que non están ligados per se aos referentes culturais autóctonos; FV preséntase como xornal que emprega e

\footnotetext{
${ }^{18}$ Remataba na semana en cuestión unha colección de novelas de Premios Nobel en castelán, que se promociona tamén nesta lingua (cfr. LVG (16/09/03): 10).

19 Véxase o anuncio en castelán na cabeceira en galego en GH (16/09/03): 27, por exemplo.

${ }^{20}$ Cremos que só se podería determinar con maior exactitude a relación que cada cabeceira quere manter coas linguas da Comunidade de examinarmos diacronicamente as autopromocións dos últimos anos.

21 Véxase un exemplo desta autopromoción en FV (16/09/03): 6. A cabeceira insire todos os días anuncios promocionais da súa sección de anuncios por palabras, e sempre en castelán (por exemplo FV (16/09/03): 57, 59, 61).
} 
está ligado basicamente co castelán -agás unha incursión culturalista e literaria no galego-, en tanto que nos xornais do Grupo Correo Gallego a imaxe distribúese entre cabeceiras: GH preséntase ligado ao galego, ECG ao castelán.

Hai que facer mención, por último, ao moi escaso peso da estratexia autopromocional nestes dous diarios, e en especial en ECG, feito que se nos ocorre relacionar cunha peculiaridade do xornal que destaca Álvarez Pousa (1999: 167) e a que nos referimos anteriormente, no apartado 3.2 do traballo: a elevada proporción de lectores de clase media-alta con que parece contar ECG, probablemente por causa do definitivo peso social e económico que teñen a Universidade e a administración autonómica na cidade de Santiago. En xeral, as estratexias de autopromoción, e de agasallos publicitarios, táchanse de populistas, pois tenden a captar o interese circunstancial de sectores sociais pouco podentes. Quizais haxa mesmo un intento consciente, por parte da cabeceira e da editorial, de se desmarcar dunha liña de promoción de vendas que conta con tan mala fama e, polo que din os especialistas, tamén presenta malos resultados.

\subsection{A lingua galega e a publicidade institucional (gráficos 7,8 e 9)}

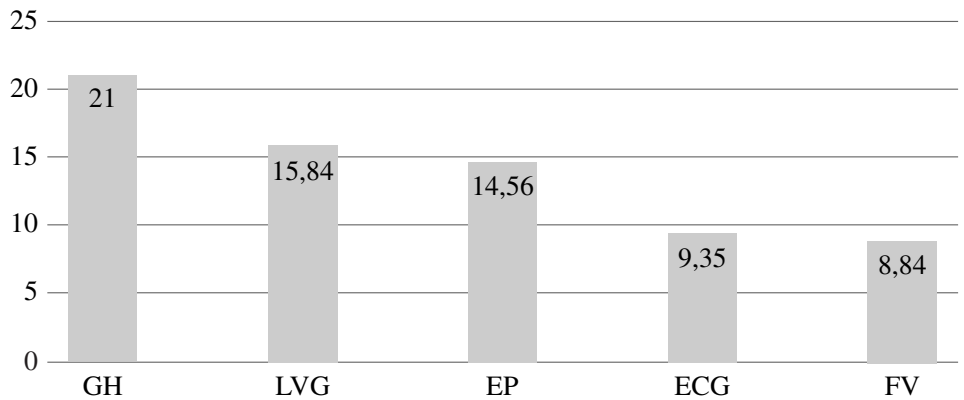

Gráfico 7. Porcentaxe de publicidade institucional.

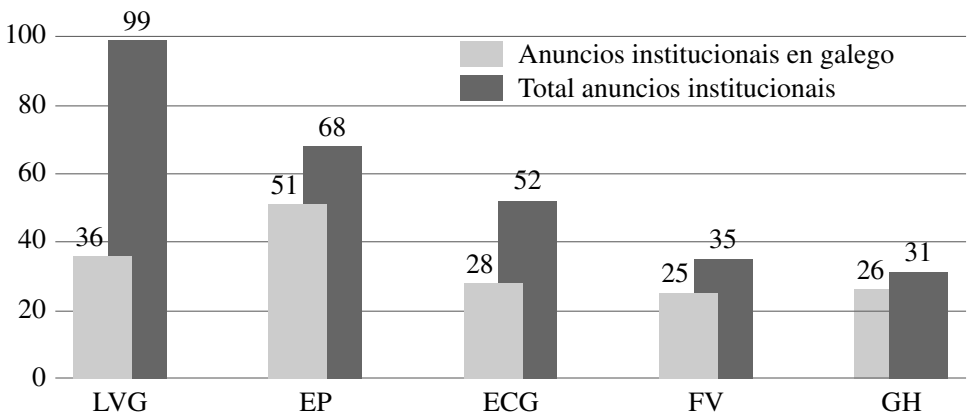

Gráfico 8. Publicidade institucional. 


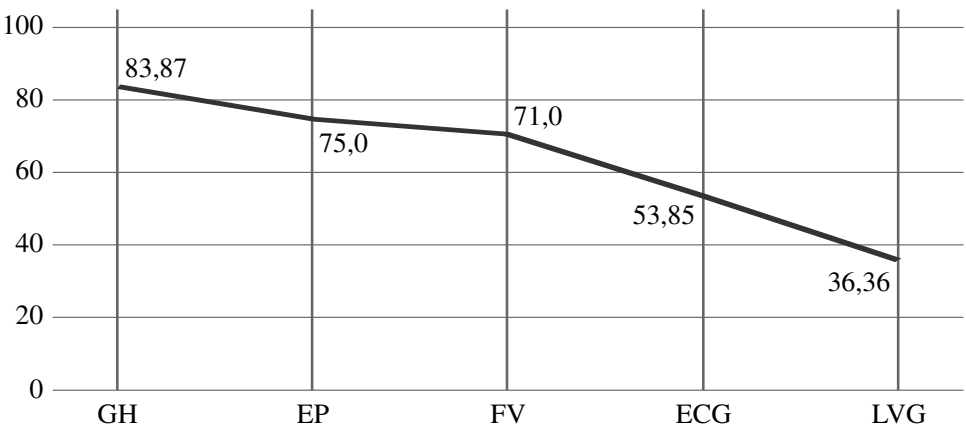

Gráfico 9. Publicidade institucional en galego (\% sobre o total).

Segundo vimos no apartado 3.3 do traballo, algúns dos estudos que presentan cifras para a análise da lingua dos xornais galegos afirman que é a publicidade institucional a que "salva" as porcentaxes de galego na prensa, do que podería deducirse que se suxire a existencia dunha relación directa entre este tipo de publicidade e a nosa lingua. Os números obtidos a partir do noso corpus permiten cuestionar esta interpretación, que é válida unicamente nalgunhas cabeceiras.

Presentamos en primeiro lugar datos que teñen que ver co peso relativo que ten a publicidade institucional no total de mensaxes publicitarias que se insiren en cada cabeceira (gráfico 7). GH aparece como o xornal máis dependente deste tipo de financiamento, pois un 20,53\% dos anuncios que acolle son deste tipo. LVG e EP rondan o $15 \%$; ECG e FV, en fin, sitúanse un pouco por debaixo $(9,35 \%$ e 8 , $84 \%$ ). En calquera caso, a importancia do fenómeno como fonte de financiamento debe ser grande, a xulgar pola entidade dos valores porcentuais que manexamos.

O exame dos gráficos 8 e 9 permite desbotar o lugar común que permitiría falar da "galeguización" da publicidade institucional. Nin sequera no caso de GH todos os anuncios que proceden das administracións están en galego, aínda que si unha máis que avultada porcentaxe $(83,87 \%$ do total). Algo similar ocorre no caso de FV que é, debémolo lembrar, a cabeceira en que a publicidade institucional ten un menor peso; pero fronte a este dato, cabe destacar a cifra que ofrece LVG, con moito o xornal que máis anuncios de carácter institucional insire: só un 36,36\% destes está en galego. Para explicar esta diversidade numérica entre as distintas cabeceiras hai que ter en conta, cremos, dúas circunstancias: a primeira é que fronte ao que ocorre na provincia de Pontevedra, en que a maior parte dos concellos, cando menos os que insiren publicidade en FV, utiliza para esta finalidade o galego, na Coruña e en Lugo hai entidades municipais -e tamén as deputacións- que 
empregan ben as dúas linguas ben unicamente o castelán para as mensaxes que ofrecen nos xornais ${ }^{22}$.

A segunda circunstancia importante que determina de maneira decisiva o descenso da entidade numérica dos anuncios institucionais en galego relaciónase coa publicidade de cursos, actividades de posgrao etc., promocionadas por departamentos ou áreas das Universidades galegas. A semana que seleccionei para a mostraxe implicaba un gran peso deste tipo de publicidade, e teño que dicir que a gran maioría destas actividades son difundidas en castelán, tanto pola Universidade da Coruña -en que hai xa unha certa tradición de reservar o galego para os avisos de carácter máis xeral: convocatorias de prazas de aloxamento, concursos de profesorado, pero de que logo certos departamentos anuncien as súas actividades, especialmente as de posgrao, en castelán- como tamén pola Universidade de Santiago, que dá a sensación de que acadou niveis de galeguización maiores noutros momentos, polo menos no que ten que ver con este tipo de accións formativas controladas e organizadas non directamente pola Reitoría ou Vicerreitorías, senón polos diversos departamentos de maneira, ao parecer, bastante autónoma ${ }^{23}$.

Finalmente cabe destacar, en referencia de novo ás administracións locais e provinciais, como se camiña cara a unha situación de reparto de linguas na promoción de tales institucións, en función da cal as mensaxes de autorrepresentación, aquelas que non comportan ningún tipo de utilidade para o cidadán máis que a divulgación pública da existencia e funcionamento xenéricos da institución -e indirectamente dos seus logros e dos seus dirixentes políticos- tenden a facerse xeralmente en galego (por exemplo, así ocorre na Deputación da Coruña) mentres que cando realmente o que se anuncia é unha actividade que quere, que necesita captar o interese dos lectores utilízase o castelán. A institución preséntase, daquela, como galega, pero cando quere asegurarse da lectura do texto, e provocar unha subseguinte actuación en función desta lectura, emprega unicamente o castelán ${ }^{24}$. A lóxi-

${ }^{22}$ Con respecto á Deputación da Coruña, cfr. p.e. ECG (16/03/03): 16, 20; LVG (16/03/03): 23; GH (17/09/03): 10) (anuncios de pequeno formato en castelán, en que se difunden concursos para prestar servizos á entidade) e LVG (18/09/03): $42-43$ (anuncios maiores relacionados con expropiacións e que inclúen un amplo listado de persoas afectadas), todos eles en castelán.

Cando reviso este traballo para a súa publicación, atopo xa en galego os anuncios "funcionalmente activos", de expropiacións e semellantes, que a Deputación da Coruña insire nos xornais, e felicítome por este cambio na tendencia lingüística da institución.

${ }^{23}$ Para a Universidade da Coruña pode verse, entre os moi abondosos exemplos, LVG (16/09/03): 34, 52;. Para a de Santiago véxase, p.e., ECG (16/09/03): 24. Non atopo datos no corpus relativos á Universidade de Vigo, pois talvez esta institución é máis mesurada á hora de organizar actividades académicas diferentes das regulares.

${ }^{24}$ Toda a publicidade da Deputación da Coruña que aparece no noso corpus responde a este modelo de alternancia lingüística: os moi numerosos anuncios con avisos de expropiacións, adquisicións e outras actividades económicas que implican a cidadáns concretos e diante das cales estes deben darse por informados e actuar consonte esta información aparecen sempre en castelán, en tanto que rexistro un único texto de autopublicidade da institución, en galego. 
ca é semellante á que parece rexer o comportamento lingüístico das universidades: estas preséntanse como galegas, teñen o seu logotipo e o seu nome oficial en galego, como institución global dan en galego as súas mensaxes publicitarias ou máis ben "de servizos" 25 pero cando se quere captar a atención dos posibles alumnos interesados nas súas actividades, nun contexto de competición crecente, isto é, cando xa non temos xa avisos de servizos senón propiamente anuncios, recórrese ao castelán ${ }^{26}$.

O gráfico 9, que sinala a porcentaxe de publicidade institucional en galego sobre o total de publicidade institucional, presenta unha ordenación das cabeceiras moi ligada, penso, aos comportamentos lingüísticos da Universidade da Coruña e da Deputación da Coruña. Non se pode manter, pois, sen máis, a idea da galeguidade lingüística da publicidade institucional nas cabeceiras galegas, pois esta depende moito da provincia en que nos insiramos.

\subsection{Publicidade privada en galego (gráficos 10 e 11)}

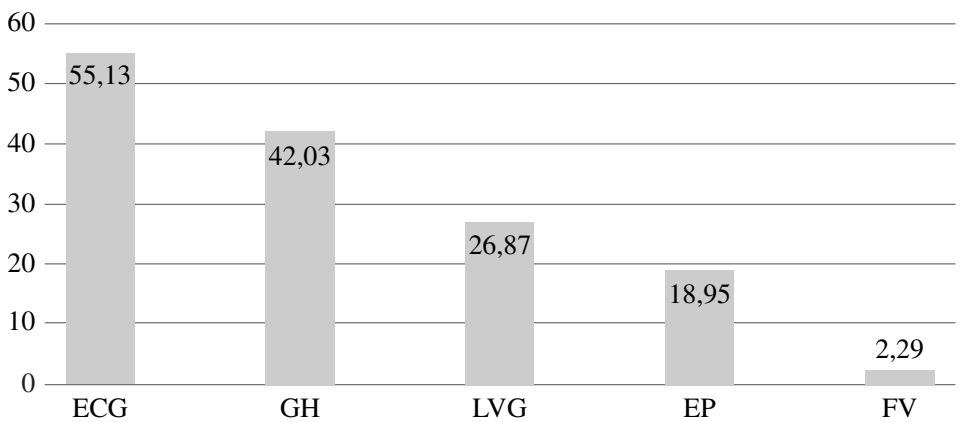

Gráfico 10. Publicidade privada en galego (en \%).

25 Valla como exemplo a convocatoria de concurso público para a provisión de profesorado universitario que a Universidade de Santiago insire nos xornais do domingo 21/09/03.

${ }^{26}$ Un terceiro caso regulado pola mesma lóxica no seu comportamento lingüístico atópoo nun Especial Terra Chá que inclúe EP o xoves 19, e que conta con varios textos publicitarios, todos eles ocupando unha páxina completa, dos concellos da bisbarra. A totalidade dos municipios da comarca, coa excepción do de Guitiriz (EP (19/09/03): IX), escolle o galego como lingua máis axeitada para proxectar a imaxe exterior que se desexa. A excepcionalidade do consistorio guitiricense pode ser comprendida de termos en conta a natureza dos contidos polos que este opta no seu anuncio: non se trata tanto de remarcar os valores paisaxísticos ou culturais do seu concello, senón de anunciar, incluíndo mapas e planos topográficos, a importante dispoñibilidade de solo industrial en óptimas condicións de emprazamento con que conta o municipio. Paisaxe, cultura, ocio en fin, difúndense en galego; o castelán, por contra, parécelles aos rexedores deste concello a lingua axeitada para promocionar un espazo industrial de futuro. A lóxica que regula a alternancia lingüística non difire moito, desde o meu punto de vista, da que observamos na publicidade da Deputación da Coruña ou na dos cursos de posgrao das universidades galegas. 


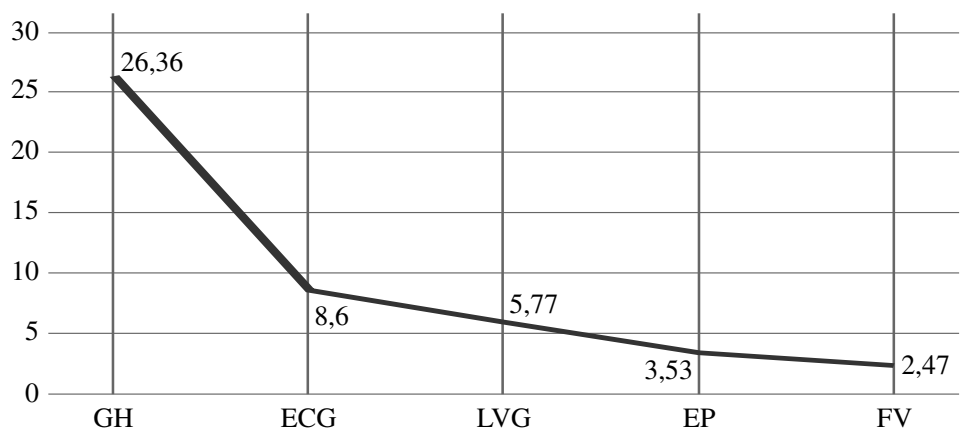

Gráfico 11. Anuncios privados en galego.

Neste traballo optei, sen excesivo convencemento e case que como mal menor, polo emprego da denominación "publicidade privada" para agrupar os textos publicitarios non institucionais e non de autopublicidade do propio diario. $\mathrm{O}$ seu peso cuantitativo dentro do total de publicidade en galego é diverso de cabeceira en cabeceira, como se pode deducir da observación do gráfico 10 dos que presentamos: mentres que en ECG o 55,13\% do total de anuncios en galego é privado, en FV esta porcentaxe non chega ao 3\% (2,29\%). Os dous xornais do Grupo Correo Gallego son conxuntamente aqueles en que a importancia relativa da publicidade privada en galego é maior, en tanto que LVG e EP sitúanse de novo próximos na entidade numérica da escolla do galego para este xénero publicitario (entre o 20 e o $30 \%$ dos anuncios privados está na nosa lingua).

Aínda que non é a intención deste traballo a de presentar un detallado das entidades ou empresas que empregan o galego na súa publicidade, si parece preciso facer mención daquelas que, polo seu papel económico ou polo seu tamaño, posúen un relevo especial. Entre as inmobiliarias, que en Santiago teñen moita importancia en prensa, son minoría, pero existen, aquelas que manteñen constantemente a súa publicidade en galego nas dúas cabeceiras do Grupo Correo Gallego ${ }^{27}$ (algunhas promotoras cambian segundo sexa a publicidade para ECG ou para GH). O sector das academias aparece tamén como levemente galeguizado, de seguro por causa da vinculación entre escola e lingua no ensino regular ${ }^{28}$. Tamén hai ONGs como Meniños $^{29}$, adegas como Via Romana ${ }^{30}$ e asociacións sen ánimo de lucro como

\footnotetext{
27 Coñecido é o caso do Grupo Otero Pombo, xa mencionado en Ramallo e Rei-Doval (1996) (cfr. por exemplo ECG (16/09/03): 29).

${ }^{28}$ Vfr., a modo de exemplo, ECG (21/09/03): Especial 2, Especial 5.

29 Por exemplo, GH (16/03/09): 23.

${ }^{30}$ Por exemplo, ECG (21/09/03): 19.
} 


\begin{abstract}
ALCER, que utiliza as dúas linguas ${ }^{31}$; grandes áreas comerciais como Área Central $^{32}$ ou Carrefour ${ }^{33}$, pero non o Centro comercial aberto de $\operatorname{Lugo}^{34}$. Unha empresa concesionaria de servizos públicos, Vitrasa -adxudicataria dos autobuses do concello de Vigo- insire en FV (17/09/03) un peculiar anuncio que se caracteriza sobre todo polo hibridismo lingüístico, peculiaridade que non é allea a outros textos publicitarios dos que forman parte da nosa escolma. Así mesmo, atopo en galego textos publicitarios nas páxinas dedicadas, como especiais ou de maneira máis constante, a ámbitos xeográficos menores, supostamente máis galegófonos: trátase de pequenas empresas de servizos como panadarías de determinadas áreas xeográficas, electricistas que teñen o seu ámbito de traballo en pequenos concellos ou comarcas concretas etc. ${ }^{35}$.
\end{abstract}

Con todo, se examinamos o gráfico 11 veremos como a importancia relativa da publicidade en galego no conxunto da publicidade privada é sempre pequena, pois ao máximo que chegamos é a ter un cuarto da publicidade en galego en GH, e lembremos que esta é a cabeceira que menos anuncios insire e na que a proporción de textos institucionais é maior. Para o resto dos xornais, as cifras oscilan entre o 8,6\% de ECG e o $2.47 \%$ de FV, así que están sempre por baixo do $10 \%$. Se a publicidade institucional non se pode cualificar en absoluto de plenamente galeguizada, si que cabe concluír que o está nunha proporción superior ás mpromocións privadas.

Por último, gustaríanos sinalar que a tendencia a que faciamos alusión no apartado anterior como propia do mundo institucional, e que consiste en empregar o galego preferentemente nos anuncios publicitarios de autorrepresentación -naqueles en que o que se procura é a transmisión dunha "imaxe pública" de determinada entidade- en tanto que se insiren en castelán os textos que procuran unha resposta efectiva por parte do receptor, tamén se detecta entre algunhas das empresas galegas, e nomeadamente no caso das caixas de aforros: a "obra social", que ten

31 Por exemplo, EP (17/03/09): 8 (en galego) e EP (21/09/03): 42 (en castelán).

32 Véxase, p.e. ECG (21/09/03): Vida Social Gallega 12.

33 As mensaxes que esta grande área comercial inseriu nos xornais, así como os folletos que deseñou para as caixas de correo, tras asinar un acordo con Política Lingüística para a galeguización da súa publicidade, darían, por si sós, para un estudo de grande interese sobre o emprego das linguas de Galicia. Non atopei nin recordo mensaxe publicitaria ningunha de Carrefour unicamente en galego, e aínda que non podo entrar en detalles sobre o particular neste momento, a alternancia de linguas dista moito de ser inmotivada ou azarosa. Véxase, a modo de exemplo, EP (18/09/03): 5.

${ }^{34}$ Por exemplo LVG (16/09/03): L[ugo] 13; EP (16/09/03): 9; EP (18/09/03): 11. Nin a publicidade desta iniciativa de agrupamento comercial nin a rotulación específica que se achegou aos centros que a ela se adheriron está en galego, a pesar de que nos anuncios xornalísticos menciónanse tanto o Concello de Lugo como a Consellaría de Innovación, Industria e Comercio da Xunta de Galicia, entidades que supoñemos a financian nalgunha medida.

${ }^{35}$ Cfr. p.e. EP (18/09/03): Especial Terra Chá XXX, XXXII; ECG (18/09/03): 39. 
como finalidade central a de proxectar imaxe cara ao exterior, aparece en galego en moitos anuncios tanto de Caixa Galicia (p.e. EP (18/09/03): 19; FV (18/09/03): 23) como de Caixanova; tamén a autopublicidade de ambas as entidades financeiras, que non ten máis obxectivo que o de lembrarlles aos cidadáns a simple existencia das institucións, vai na nosa lingua; pero cando se trata de divulgar as características dos produtos concretos que se ofertan, como por exemplo o xuro da hipoteca e as virtualidades das tarxetas de crédito de cada empresa, os textos insírense en castelán ${ }^{36}$. Noutras destacadas empresas de Galicia, como Pescanova, nin sequera se proxecta en galego a súa imaxe como galega, e iso que o establecemento dun vínculo entre a entidade e Galicia se erixe no contido fundamental do anuncio (véxase p.e. LVG (17/09/03): World Fishing Exhibition Vigo 2003, 41; ECG (18/09/03): 9). Tampouco Citroën ${ }^{37}$, aínda que neste último caso interpretamos o comportamento lingüístico da empresa na publicidade a partir do non interese en proclamar a galeguidade dunha institución de marcado carácter supranacional.

${ }^{36}$ Para Caixanova, véxanse por exemplo FV (17/09/03): 11; ECG (21/09/03): Correo das Culturas 8. Así e todo, non hai unha continuidade absoluta na utilización "simbólica" do galego: por exemplo, en FV (15/09/03): 5 a entidade bancaria anuncia en castelán a función El sueño de una noche de verano, supoñemos que nunha busca de coherencia coa lingua da representación. Así mesmo, en FV (17/09/03): 29 vai en castelán a publicidade da exposición Juan Gris en las colecciones del Museo Nacional Reina Sofía, e en FV (17/09/03): 36-37 a do seu Centro Interactivo de Educación Medioambiental. Tamén en castelán se anuncia o Ciclo Caixanova de Teatro y Danza celebrado no teatro Rosalía de Castro da Coruña (LVG (18/07/03): 13), talvez polo patrocinio do consistorio da cidade herculina.

Caixa Galicia, pola súa banda, insire en FV(17/09/03): World Fishing Exhibition Vigo 2003: 11 e LVG (17/09/03): World Fishing Exhibition Vigo 2003:21 (nas páxinas dedicadas por ambos os xornais á Feira Mundial da Pesca) un anuncio unicamente de imaxe corporativa e en castelán. Cremos que este conxunto de feitos debe interpretarse como que as dúas entidades financeiras procuran un vínculo simbólico coa lingua, pero non están interesadas en que este se interprete como excesivamente intenso por medo a que se valore en termos de exclusión. A excepcionalidade das páxinas dedicadas á Feira Mundial da Pesca, destinadas a seren lidas por non galegos en boa medida, pode explicar tamén en boa parte as escollas lingüísticas desta empresa, pois mesmo a administración autonómica insire un anuncio de autopublicidade en castelán en tales suplementos.

Cremos que Caixa Galicia acada un nivel de galeguización publicitaria, na dimensión institucional , maior do que Caixanova. Esta última empresa parece que toma decisións lingüísticas máis concretas, pertinentes para cada anuncio en particular, e desde logo non quere que a súa relación co galego sexa susceptible de se entender en termos de plenitude ou exclusividade. Na dimensión comunicacional, o comportamento de ambas as institucións é idéntico, e os anuncios que presentan un alcance real, que non son de autorrepresentación, están sempre en castelán (cfr. por exemplo FV (16/09/03): 30, 32-33). O Banco Pastor tamén emprega o castelán en exclusiva para a publicidade dos seus produtos financeiros (p.e. EP (17/09/03): 43).

37 A empresa non emprega o galego nin na dimensión institucional da súa publicidade (p.e. LVG (17/09/03), Word Fishing Exhibition, Vigo, 2003: 17) nin tampouco cando anuncia as súas ofertas (p.e. FV (15/09/03): 7). A situación é parcialmente distinta no caso de Seat, que difunde en galego as súas ofertas nalgúns xornais (p.e. EP (17/09/03): 5) e noutros, en castelán (p.e. FV (17/09/03): 4), non sei se por decisión do concesionario ou por outro tipo de razóns. 
De todo o dito cabe, ao noso xuízo, concluír a existencia de tres chanzos no comportamento lingüístico publicitario das empresas galegas: as que empregan unicamente o galego, en todo tipo de mensaxes - esta categoría está baleira no período que eu estudei no relativo ás grandes empresas, e é excepcional nas pequenas-; as que empregan o galego para a autorrepresentación, para proxectar imaxe cara ao exterior, á maneira do que acontece en boa parte das institucións do país, pero para outro tipo de mensaxes, máis prácticas e centradas nos produtos que efectivamente tentan vender, seleccionan o castelán (é dicir, fan uso do capital simbólico da lingua, pero non do comunicacional): é o caso das caixas galegas, aínda que tampouco non en plenitude; por último, existen empresas que non utilizan nin sequera a lingua a efectos de imaxe, ás veces porque non teñen interese en seren asociadas como galegas (Citroën), outras si se venden como galegas, pero renunciando a transmitir ningún tipo de vínculo entre lingua e identidade (Pescanova).

\subsection{Anuncios de gran formato (gráfico 12)}

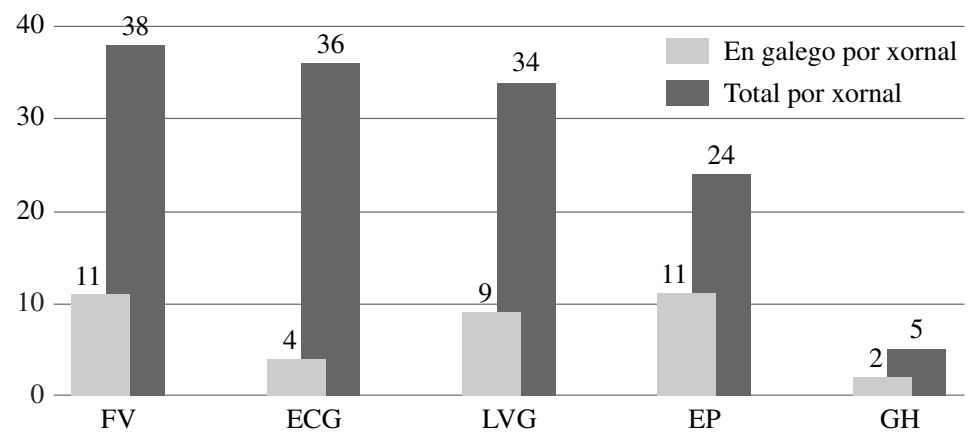

Gráfico 12. Anuncios de gran formato.

Finalmente, para caracterizar a utilización da lingua nas diversas cabeceiras hai que ter en conta a tipoloxía de textos publicitarios que se insiren, a que non fixemos referencia ata o momento e que é moi importante: hai diversos tamaños, desde anuncios en dobre folla, dereita-esquerda (só hai un no noso corpus, LVG (21/09/03): 14-15) ata minúsculas mensaxes que ocupan pouco máis de 3 por 3 centímetros. Hai tamén anuncios en cor, sexa cal sexa o seu tamaño, e outros en branco e negro. Non estudamos polo miúdo a relación entre lingua e tipo de anuncio en concreto, pero como mostra si sinalamos a aparición de textos en galego entre os anuncios de gran formato, frecuentemente a cor, que son aqueles que ocupan toda unha páxina, a dereita (porque aínda que hai estudos que din que non fixamos a atención necesariamente máis nos anuncios da dereita do que nos da esquerda, o certo é que sempre houbo esta impresión, e hai máis anuncios nesta páxina que na outra). Cabe subliñar que a cifra se ve aínda incrementada polo feito de que 
a TVG insería no período estudado información diaria sobre o máis destacado da súa programación, e en todos os xornais excepto en ECG -en que ten un tamaño algo máis pequeno- escolleu sempre o gran formato e sempre o branco e negro (por exemplo EP (18/09/03): 66; FV (18/09/03): 75). Con todo, nos xornais en que realmente hai un importante peso cuantitativo deste tipo de anuncios de maior tamaño, que son FV, ECG e LVG, a presenza do galego neste tipo de mensaxes é pequena. Frecuentemente son campañas de ámbito estatal, e mesmo en $\mathrm{GH}$ a utilización do galego é minoritaria neste tipo de publicidade.

\section{Conclusións}

Creo que se pode afirmar de maneira global que a publicidade que se insire nos xornais galegos que tomamos como referencia está pouco galeguizada en cifras absolutas. Nunha caracterización de tipo cualitativo, direi que a publicidade en galego aparece claramente orientada cara ao ámbito dos servizos públicos, ou máis ben que a lingua forma parte da representación de si mesmas que as institucións que prestan estes servizos (concellos, deputación, ensino, sanidade, organizacións non gobernamentais e sen ánimo de lucro) queren proxectar cara á sociedade: boa parte delas preséntase como galegas e escollen o galego como medio de axudar a transmitir esta imaxe. Trátase dunha utilización da dimensión simbólica da lingua. Por contra, cando estas mesmas institucións teñen realmente algo que dicir, queren asegurarse de que a súa mensaxe chegue aos cidadáns coa finalidade de que estes actúen en consecuencia (fagan un posgrao, déanse por informados dun proceso de expropiación, participen nun concurso, etc.), o grao de galeguización das súas mensaxes é moito menor, coma se dubidasen da eficacia da lingua en termos prácticos. A dimensión comunicativa é percibida como deficitaria xa non só polo sector privado da economía, senón tamén, e isto parece máis grave, por amplas parcelas do sector público.

No mundo da empresa privada, as cifras son máis alarmantes aínda. Só hai un certo grao de galeguización publicitaria por parte daqueles sectores que teñen tamén un papel institucional, maior ou menor: as caixas galegas, por exemplo. Fóra disto atopamos mensaxes en galego de xeito moi minoritario e sempre dentro da excepcionalidade. O sector comercial, de tanto peso na publicidade en prensa e tan apoiado economicamente polas institucións, só excepcionalmente escolle o galego para a difusión da súa imaxe corporativa.

Por xornais, cabe destacar o importante peso cuantitativo, en termos relativos, dos textos en galego nas cabeceiras da Editorial Compostela. Cremos que a situación é consecuencia da importancia económica da lingua nunha cidade como Santiago, que vive basicamente de institucións públicas moi vencelladas á dimensión simbólica a que nos referiamos anteriormente. EP e LVG son comparables pois ambos 
De todo o dito cabe, ao noso xuízo, concluír a existencia de tres chanzos no comportamento lingüístico publicitario das empresas galegas: as que empregan unicamente o galego, en todo tipo de mensaxes - esta categoría está baleira no período que eu estudei no relativo ás grandes empresas, e é excepcional nas pequenas-; as que empregan o galego para a autorrepresentación, para proxectar imaxe cara ao exterior, á maneira do que acontece en boa parte das institucións do país, pero para outro tipo de mensaxes, máis prácticas e centradas nos produtos que efectivamente tentan vender, seleccionan o castelán (é dicir, fan uso do capital simbólico da lingua, pero non do comunicacional): é o caso das caixas galegas, aínda que tampouco non en plenitude; por último, existen empresas que non utilizan nin sequera a lingua a efectos de imaxe, ás veces porque non teñen interese en seren asociadas como galegas (Citroën), outras si se venden como galegas, pero renunciando a transmitir ningún tipo de vínculo entre lingua e identidade (Pescanova).

\subsection{Anuncios de gran formato (gráfico 12)}

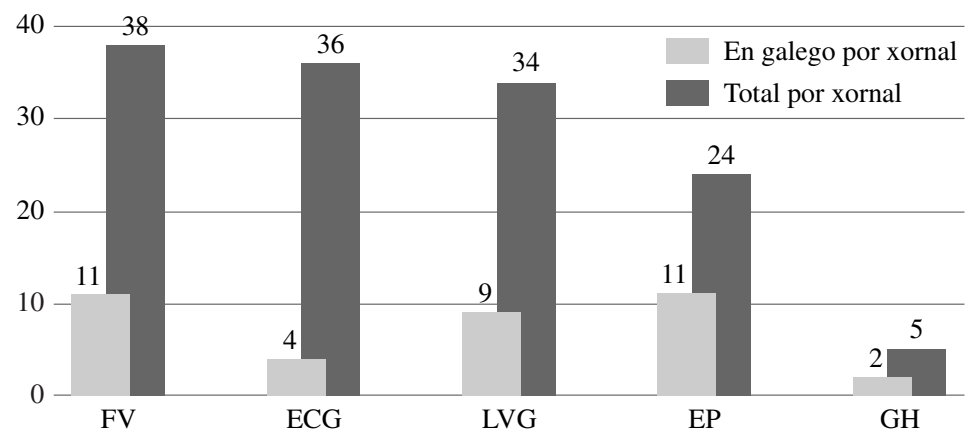

Gráfico 12. Anuncios de gran formato.

Finalmente, para caracterizar a utilización da lingua nas diversas cabeceiras hai que ter en conta a tipoloxía de textos publicitarios que se insiren, a que non fixemos referencia ata o momento e que é moi importante: hai diversos tamaños, desde anuncios en dobre folla, dereita-esquerda (só hai un no noso corpus, LVG (21/09/03): 14-15) ata minúsculas mensaxes que ocupan pouco máis de 3 por 3 centímetros. Hai tamén anuncios en cor, sexa cal sexa o seu tamaño, e outros en branco e negro. Non estudamos polo miúdo a relación entre lingua e tipo de anuncio en concreto, pero como mostra si sinalamos a aparición de textos en galego entre os anuncios de gran formato, frecuentemente a cor, que son aqueles que ocupan toda unha páxina, a dereita (porque aínda que hai estudos que din que non fixamos a atención necesariamente máis nos anuncios da dereita do que nos da esquerda, o certo é que sempre houbo esta impresión, e hai máis anuncios nesta páxina que na outra). Cabe subliñar que a cifra se ve aínda incrementada polo feito de que 
importante e positiva en termos de difusión da cabeceira, pois talvez os posibles lectores de GH apostasen de mellor gana polo xornal se este arriscase máis no seu compromiso coa lingua.

En termos xerais, mesmo naquelas cabeceiras que decidiron aproveitar a dimensión simbólica da lingua como unha compoñente máis dos seus proxectos de expansión, o que se nota é a existencia dun gran receo por parte das empresas editoras e tamén dos anunciantes. Dubídase xa non só da capacidade comunicativa da lingua por causa dos déficits de comprensión do galego escrito que o receptor implícito poida ter, senón que -e isto parece aínda máis grave- tampouco non se procura un vínculo simbólico co galego que sexa tan forte como para ser percibido como excesivo por sectores significativos, e sobre todo significados, do posible público. Sintetizando, diremos que as empresas, tanto as editoriais como as doutro tipo, tampouco confían nas enquisas.

\section{Referencias bibliográficas}

Alonso, F. (1994): “1993: a situación do galego na prensa”, en Sánchez Puga, X. (coord.): Xornadas de Formación en Lingua Galega para os Equipos de Normalización Lingüística dos Centros Educativos (1993): 257-267 (Santiago: Xunta de Galicia, Consellaría de Educación e Ordenación Universitaria, Dirección Xeral de Política Lingüística).

Álvarez Pousa, L. (1999): “A prensa diaria de información xeral”, en A identidade fronte á rede. $O$ reto mediático de Galicia na sociedade da información: 153-180 (Vigo: Xerais).

Asociación para la Investigación de Medios de Comunicación (2003): Estudio General de Medios. Febrero a noviembre de 2003 (www.aimc.es).

Campos Freire, F. (1995): "Entrevista [a Francisco Campos Freire, Director Xeral da CRTVG]", en Radio Televisión de Galicia. Dez anos de prodixios, suplemento de La Voz de Galicia, 24/07/95: 4-7.

Campos [Freire], F. (1999): "Xestión e tendencias das empresas e grupos galegos de comunicación”, en López García, X. e Campos Freire, F. (eds.): As fronteiras do novo xornalismo. Actas do curso da UMP celebrado en setembro de 1997 no Pazo de Mariñán: 115-125 (Santiago: Lea).

Campos [Freire], F. (2002): "O novo mapa dos grupos de comunicación no século XXI”, en López García, X. (ed.): A comunicación en Galicia 2002: 13-38 (Santiago: Consello da Cultura Galega, Sección de Comunicación).

Campos Freire, F./ López García, X. (2000): “A prensa”, en López García, X. (coord.): A comunicación en Galicia 2000: 19-55 (Santiago: Consello da Cultura Galega, Ponencia de Comunicación). 
Cermeño, X. (1993): A publicidade, a fábrica dos desexos (Santiago: Xunta de Galicia, Consellaría de Cultura).

Díaz Nosty, B. (1999): "La difusión de la prensa diaria en lengua española", Anuario 1999 del Centro Virtual Cervantes (www.cvc.cervantes.es/obref/anuario/anuario 99/nosty02).

Fandiño Alonso, X., / Pena Rodríguez, A. (2002): “A publicidade en Galicia”, en López García, X. (coord.): A comunicación en Galicia 2002: 87-100 (Santiago: Consello da Cultura Galega, Sección de Comunicación).

Fernández Rei, F. (1991): "A lingua galega na prensa escrita. Interferencias lingüísticas”, en Rojo, G. / Fernández Rei, F. / Martínez, R. / Campos, F.: As linguaxes dos medios de comunicación en Galicia: 31-58 (Santiago: Lea).

Ferro Ruibal, X. (1998): "Porcentaxes de galego na prensa diaria. Dúas catas en outubro e novembro de 1998", Cadernos de lingua, 18: 29-51.

Freixanes, V. Fernández (1994): A lingua galega nos medios de comunicación. Proposta de análise dos aspectos simbólicos e comunicacionais da lingua a través das institucións de socialización. Tese de doutoramento, Universidade de Santiago (inédita).

Goyanes Villar, H. (1993): “A lingua”, en Rivas, M: Informe da Comunicación en Galicia: 183-196 (Santiago: Consello da Cultura Galega).

Goyanes Villar, H./ Núñez Singala, M. C. / Romero Rodríguez, P. / Túñez López, M. (1996): A información en galego. (Santiago: Lea).

Gutiérrez González, P.P. (1996): “La pequeña publicidad. Una reflexión sobre la actividad publicitaria con bajos presupuestos y desde estructuras empresariales reducidas", en Fernández Areal, M. (dir.) / Ramos Fernández, F. (coord.): La comunicación publicitaria. Terceras Jornadas de Comunicación social (Pontevedra, del 1 al 5 de octubre de 1996): 53-81 (Pontevedra: Deputación Provincial).

Iglesias Álvarez, A. (2002): Falar galego: "no veo por qué". Aproximación cualitativa á situación sociolingüística de Galicia (Vigo: Xerais).

López García, X. (2000): A prensa do terceiro milenio (Santiago: Lea.)

López [García], X. (2002): “A prensa ensaia cambios nos contidos e novas estratexias para evita-la perda de lectores", en López García, X. (coord.): A comunicación en Galicia 2002: 41-50 (Santiago: Consello da Cultura Galega).

Martínez, V.A. (1999a): Distribución da prensa diaria en Galicia (Santiago: Lea).

Martínez, V. A. (1999b): “Os xogos como instrumento de márketing na empresa xornalística", en López García, X. / Campos Freire, F. (coords.): As fronteiras do novo xornalismo. Actas do curso da UMP celebrado en setembro de 1997 eno Pazo de Mariñán: 75-85 (Santiago: Lea). 
Martínez, V. A. (2002): "Estratexias de mercadotecnia na comercialización da prensa diaria: grandes tendencias", en López García, X. (coord.): A comunicación en Galicia 2002: 177-182 (Santiago: Consello da Cultura Galega).

Monteagudo, H. / Bouzada, X. (coords.) (2002): O proceso de normalización do idioma galego (1980-2000). Volume I. Política lingüística: análise e perspectivas (Santiago: Consello da Cultura Galega, Sección de Lingua).

Pena Rodríguez, A. (2000): “A publicidade”, en López García, X. (coord.): A comunicación en Galicia 2000: 169-181 (Santiago: Consello da Cultura Galega, Ponencia de Comunicación).

Ramallo, F. [Fernández] (2002): “O galego na publicidade: modelos culturais, representacións colectivas e comunicación publicitaria", en Mayo Redondo, S. (coord.): Actas dos IV Encontros para a Normalización Lingüística (Santiago de Compostela, 9 e 10 de novembro de 2000): 131-151 (Santiago de Compostela: Consello da Cultura Galega, Ponencia de Lingua).

Ramallo, F. Fernández / Rei-Doval, G. (1995): Publicidade e lingua galega (Santiago: Consello da Cultura Galega).

Ramallo, F. Fernández / Rei-Doval, G. (1996): Vender en galego (Santiago: Consello da Cultura Galega).

Real Academia Galega (2001a): "Manifesto á prensa sobre o uso do galego (Texto aprobado polo pleno de 9.4.1999 que reciben tódolos medios de comunicación o xoves 15.4.1999)", Boletín da Real Academia Galega, 362: 323-327.

Real Academia Galega (2001b): "Propostas da Real Academia Galega ó Goberno e mais ó Parlamento de Galicia (aprobadas na sesión do 8 de setembro do 2001)”, (www.acontrafio.com/docu normalizacion.htm).

Reig, R. (1998): Medios de comunicación y poder en España (Barcelona: Paidós).

Vaamonde Liste, A. (coord.) (2002): Estudio sociolingüístico sobre a situación da lingua galega no Concello de Vigo 2002 (Vigo: Concello de Vigo).

Vilela Conde, X. L. (2001): “Crise? ¿que crise?”, en López García, X. (dir.): Jornadas sobre tendencias en el periodismo: 235-247 (Santiago: Escola Galega de Administración Pública). 